\title{
Ensaio: A Organização Mundial do Comércio e os Blocos Econômicos Regionais
}

\author{
Pedro Infante Mota
}

Resumo: 0 regionalismo está na moda e, por essa razão, a relação entre o regionalismo e o multilateralismo é um dos tópicos centrais da política comercial dos dias de hoje. Alguns observadores acreditam que a proliferação de blocos econômicos regionais põe em causa o sistema comercial multilateral. Outros acreditam que a liberalização regional contribui positivamente para a liberalização global. Em nossa opinião, apesar de os blocos econômicos regionais serem mais um complemento do que uma ameaça ao sistema GATT/0MC, a via multilateral deve merecer a preferência de todos nós.

Palavras-chave: Integração Econômica, Blocos Econômicos Regionais, Acordo Geral sobre Pautas Aduaneiras e Comércio, Organização Mundial do Comércio.

Abstract: Regionalism is in fashion and, for that reason, the relationship between regionalism and multilateralism is one of the central topics of contemporary trade policy. Some observers believe that the proliferation of regional economic blocs undermines the multilateral trading system. Others believe that regional liberalization provides a positive spur to global liberalization. In our opinion, in spite of the fact that the regional economic blocs are more building blocs than stumbling blocs to the WTO/GATT System, the multilateral liberalization is the way that must deserve our preference.

Keywords: Economic Integration, Regional Economic Blocs, General Agreement on Tariffs and Trade, World Trade Organization.

\section{Introdução}

Quando o Acordo Geral sobre Pautas Aduaneiras e Comércio ${ }^{1}$ entrou em vigor no dia 1 de Janeiro de 1948, a exceção mais significativa à cláusula da nação mais favorecida

\footnotetext{
Assistente da Faculdade de Direito da Universidade Clássica de Lisboa.E-mail: pedroinfante@mail.fd.ul.pt ${ }^{1}$ Em inglês, General Agreement on Tariffs and Trade, vulgarmente conhecido pela sigla GATT.
} 
era constituída pelos chamados regimes preferenciais históricos (art. I, nos 2 a 4, do GATT) ${ }^{2}$. Os blocos econômicos regionais eram poucos e pequenos, sendo o Benelux provavelmente o mais importante ${ }^{3}$. Com a criação da Comunidade Econômica Européia em 1958, porém, tudo se alterou ${ }^{4}$.

Durante a vigência do GATT de $1947^{5}$, noventa e oito blocos econômicos regionais foram notificados ao abrigo do art. XXIV do GATT e quinze ao abrigo da Cláusula de

${ }^{2}$ John Croome, Reshaping the World Trading System. A History of the Uruguay Round, World Trade Organization, Genebra, 1995, pp. 98-99. Embora tivessem visto a sua legitimidade reconhecida pelo GATT, os regimes preferenciais históricos ficaram sujeitos a dois tipos de obrigações: i) negociar a eliminação gradual das margens preferenciais em troca de concessões equivalentes; e ii) não aumentar as margens preferenciais. Com o tempo, os regimes preferenciais históricos sofreram alterações ou deixaram simplesmente de existir. Por exemplo, o regime preferencial francês autorizado no anexo B do GATT transformou-se num acordo especial entre a Comunidade Européia e os territórios listados no anexo (alguns territórios tornaram-se, entretanto, independentes), o regime preferencial entre os EUA e Cuba, mencionado no art. I, n. ${ }^{\circ}$ 2, alínea c), do GATT, desapareceu com o fim das relações econômicas entre os dois países, decretado pelo Presidente Kennedy em 3 de Fevereiro de 1962. A perda de importância dos direitos aduaneiros, por causa dos sucessivos ciclos de negociações comerciais, contribuiu igualmente para que estes regimes preferenciais tenham, hoje em dia, um interesse, quase que diríamos, meramente histórico.

${ }^{3}$ Ao contrário do que geralmente se pensa, o fenômeno da integração econômica não é recente. Por exemplo, o Acto de União de 1703, celebrado entre a Inglaterra e a Escócia, estabeleceu, não só uma união política, como também uma união econômica; a própria criação dos EUA, dado que as colônias americanas aplicavam regimes aduaneiros distintos, o que passou a ser proibido pela Constituição (art. 1. ${ }^{\circ}$, seção VIII, n. ${ }^{0}$ 1) (cf. Fritz Machlup, A History of Thought on Economic Integration, The Macmillan Press, Londres, 1977, pp. 105-109). Em contrapartida, a expressão "integração econômica internacional" tem uma história bastante curta, visto que Fritz Machlup, no seu importante estudo da história do pensamento sobre integração econômica, não conseguiu encontrar um único exemplo do seu uso anterior a 1933. Cf. Idem, p. 7.

${ }^{4}$ Ao que parece, o problema dos blocos econômicos regionais constituírem uma exceção à cláusula da nação mais favorecida surgiu com a primeira união aduaneira alemã, em 1828. Cf. Joaquim-Joan Forner I Delaygua, La cláusula de la nación más favorecida: la excepción de las uniones aduaneras, de las zonas de libre cambio y de las uniones econômicas, Cívitas, Madrid, 1988, p. 42.

${ }^{5} 0$ GATT de 1947 vigorou até à entrada em funções da Organização Mundial do Comércio, em 1995, tendo sido então substituído pelo chamado GATT de 1994. Apesar disso, o GATT de 1994 inclui o texto do GATT de 1947 tal como ele se encontrava em vigor no dia 31 de Dezembro de 1994. A única exclusão relevante prende-se com 0 famoso Protocolo de Aplicação Provisória, nos termos do qual cada parte contratante podia manter em vigor legislação nacional incompatível com a Parte II do GATT. 
Habilitação ${ }^{6}$. Mesmo os EUA, resistentes de longa data a toda a participação em blocos econômicos regionais ${ }^{7}$, mudaram de atitude, tendo constituído, em meados da década de 80, zonas de comércio livre com Israel e o Canadá e participado no lançamento da Cooperação Econômica Ásia-Pacífico (mais conhecida pela sigla APEC de Asia-Pacific Economic Cooperation) em $1989^{8}$. Mais recentemente, e depois da criação do Acordo de Comércio Livre da América do Norte (vulgarmente conhecido pela sigla NAFTA de North American Free Trade Agreement) em 1994, o colosso norte-americano deu o tiro de partida para a criação de uma futura zona de comércio livre aplicável a todo o continente americano? .

Em 1995, ano da entrada em funções da Organização Mundial do Comércio (OMC), $53 \%$ do comércio mundial desenrolava-se no interior de blocos econômicos regionais ${ }^{10}$ e, em Julho de 2003, apenas três dos 146 membros da OMC não participavam em

\footnotetext{
${ }^{6}$ A lista completa dos acordos regionais pode ser encontrada in Jagdish Bhagwati e Arvind Panagariya, Preferential Trading Areas and Multilateralism: Strangers, Friends, or Foes?, in Trading Blocs: Alternative Approaches to Analysing Preferential Trade Agreements, Jagdish Bhagwati, Pravin Krishna, e Arvind Panagariya ed., The Massachusetts Institute of Technology Press, 1999, pp. 79-90, Comissão Européia, Aspectos relacionados com a OMC dos Acordos Comerciais Preferenciais da UE com Países Terceiros SEC(96) 2168 final, Bruxelas, 16-11997, pp. 13-16; GATT, Analytical Index. Guide to GATT Law and Practice, 6. ${ }^{2}$ ed, 1994, pp. 797-808; Eduardo Raposo de Medeiros, Blocos Regionais de Integração Econômica no Mundo, Instituto Superior de Ciências Sociais e Políticas, Lisboa, 1998, pp. 145-149; e 0MC, Le regionalisme et le système commercial mondial, ed. OMC, Genebra, 1995, pp. 87-107.

Há cerca de 30 anos atrás, Gerard Curzon observava que "the GATT for the Americans is article I; for the Europeans, it is Articles XII and XXIV". Cf. citado in Jay Culbert, War-Time Anglo-American Talks and the Making of the GATT, in The World Economy, 1987, p. 396.

${ }^{8}$ A APEC, simples acordo informal, não tendo sido por isso notificado nos termos do n. ${ }^{\circ} 7$ do $\operatorname{art}^{\circ} \mathrm{XXIV}$ do GATT, foi criada em 1989 e tem como membros algumas das maiores potências comerciais a nível mundial: China, Coréia do Sul, Indonésia, Japão, Singapura, Taipé Chinês, Hong Kong, Rússia, Austrália, Nova Zelândia, EUA e Canadá. Desde a sua criação, a APEC tornou-se o principal meio de promoção do livre comércio e investimento na região conhecida por "Anel do Pacífico".

${ }^{9}$ Na sequência da iniciativa para as Américas, apresentada pelo Presidente George Bush em 1990, os representantes de 34 Estados americanos independentes (com exclusão de Cuba) concluíram em 1994, na cidade de Miami, um acordo para estabelecerem uma zona de comércio livre até ao ano 2005, desde o Alasca até a Patagônia. A ter sucesso, criar-se-à um bloco econômico regional com mais de 800 milhões de consumidores e o maior Produto Interno Bruto do Mundo. 0 texto da Declaração de Princípios e do Plano de Ação da Cimeira das Américas de 1994 pode ser encontrado in International Legal Materials, vol. XXXIV, 1995, pp. 808-838, e uma minuta do acordo relativo à criação de uma Área de Livre Comércio das Américas in http://www.ftaa-alca.org

${ }^{10}$ Jaime Serra et al., Reflections on Regionalism: Report of the Study Group on International Trade, Carnegie Endowment for International Peace, Washington, D.C., 1997, p. 8.0 valor de 53\% é obtido subtraindo do total do comércio mundial o comércio de todos os países que não pertencem a nenhum bloco econômico regional ou à $\mathrm{OMC}$, ou seja, infere-se que todo o comércio intra-blocos econômicos regionais é conduzido em termos preferenciais, o que não corresponde à realidade. Em primeiro lugar, porque uma parte importante do
} 
qualquer bloco regional: Taipé Chinês, Macau e Mongólia ${ }^{11}$. Muitos membros da OMC participavam mesmo em vários blocos econômicos regionais ao mesmo tempo ${ }^{12}$.

Entre as razōes apontadas para o atual fenômeno de proliferação de blocos econômicos regionais, podemos destacar as seguintes:

I) é natural que países com políticas econômicas semelhantes, politicamente próximos, avancem para alianças comerciais mais estreitas comparativamente às prevalecentes no sistema comercial multilateral. Até porque, à medida que aumenta o número de membros da Organização Mundial do Comércio, mais países têm direito ao benefício de qualquer esforço de liberalização comercial, mesmo que cedida apenas por um grupo de países, sem a prestação recíproca de quaisquer concessões comerciais. Assim sendo, alguns países que gostariam de ir mais longe hesitam, devidoà regra do consenso vigente na $\mathrm{OMC}$ e ao perigo de free riders, o que leva a que a tendência nas negociaçōes multilaterais, quando está envolvido um número elevado de países, seja a de seguir o mínimo denominador comum ${ }^{13}$;

comércio intra-blocos é conduzida em termos não preferenciais, isto é, o valor dos direitos aduaneiros é igual a zero e a sua cobrança é feita segundo a cláusula da nação mais favorecida. Em segundo lugar, porque nem todo o comércio entre os membros dos blocos econômicos regionais é realizado numa base preferencial, visto que os custos administrativos e econômicos impostos pela observância das regras de origem são, por vezes, de tal ordem que é preferível pagar os direitos aduaneiros aplicáveis segundo o tratamento da nação mais favorecida. Em terceiro lugar, porque não se tem em conta o comércio preferencial não recíproco, ou seja, o comércio realizado ao abrigo dos vários sistemas generalizados de preferências. Relevando estes três aspectos, Jean-Marie Grether e Marcelo Olarreaga concluem que, no período entre 1993 e 1997, a percentagem do comércio preferencial no Mundo se situou nos 42\% (40\% no período entre 1988 e 1992). Cf. Jean-Marie Grether e Marcelo Olarreaga, Preferential and Nonpreferential Trade Flows in World Trade, in Trade Rules in the Making: Challenges in Regional and Multilateral Negotiations, Miguel Rodríguez Mendoza, Patrick Low e Barbara Kotschwar ed., Organization of American States-Brookings Institution Press, Washington, D.C., 1999, pp. 159-179.

${ }^{11}$ OMC, Understanding the WTO, ed. OMC, Genebra, 2003, p. 63. Podem ser membros da OMC "qualquer Estado ou território aduaneiro distinto que possua plena autonomia na condução das suas relações comerciais externas" (art. XII, n. ${ }^{\circ} 1$, do Acordo que Cria a 0MC).

${ }^{12} 0$ que permite a ocorrência dos denominados sistemas "hub-and-spoke", no qual o "hub" (eixo) tem livre acesso a todos os "spokes" (raios), mas cada "spoke" somente tem liberdade de acesso ao "hub". Assim, se amanhã o Brasil celebrar acordos de comércio livre quer com os EUA, quer com a Comunidade Européia ("spokes" ou "raios"), os produtos originários do Brasil (o "hub" ou "eixo") gozarão de acesso preferencial quer ao mercado norte-americano, quer ao mercado comunitário. Em contrapartida, os produtos originários dos EUA e da Comunidade Européia só terão direito a tratamento preferencial no acesso ao mercado brasileiro. Para acabar com esta situação, os EUA e a Comunidade Européia devem celebrar entre si um acordo de comércio livre.

${ }^{13}$ Warren Schwartz e Alan 0. Sykes, The economics of the most favored nation clause, in Economic Dimensions in International Law: Comparative and Empirical Perspectives, Jagdeep S. Bhandari e Alan 0. Sykes ed., Cambridge University Press, 1997, pp. 59-61. 
II) a conversão dos EUA ao regionalismo ${ }^{14}$. Embora em finais de 2001 os EUA participassem em apenas três blocos econômicos regionais (NAFTA e acordos bilaterais zonas de comércio livre - com Israel e Jordânia), posteriormente, assinaram acordos de comércio livre com Singapura em 6 de Maio de 2003, o Chile em 6 de Junho do mesmo ano e a Austrália em 8 de Fevereiro de 2004, estando igualmente nesta data em negociações com Marrocos, Bahrein, os cinco membros do Mercado Comum da América Central e os cinco membros da União Aduaneira da África Austral, e a liderar o processo de criação da ambiciosa Área de Livre Comércio das Américas (ALCA) ${ }^{15}$;

III) o desmoronar do Bloco de Leste, que levou muitos países que antes giravam em torno da ex-URSS a celebrarem acordos de comércio livre com a Comunidade Européia e a Associação Européia de Comércio Livre (mais conhecida pela sigla EFTA de European Free Trade Association), com vista a garantirem mercados e a transição das respectivas economias para um sistema de economia de mercado $^{16}$; e

IV) o chamado "efeito dominó do regionalismo", que, encontrando a sua origem mais remota no Zollverein alemão do século XIX, implica o desejo de adesão dos países que ficam de fora da criação ou do aprofundamento dos blocos econômicos regionais ${ }^{17}$.

${ }^{14}$ Jagdish Bhagwati considerava, já em 1993, que "the main driving force for regionalism today is the conversion of the United States, hitherto an abstaining party, to Article XXIV". Cf. Jagdish Bhagwati, Regionalism and multilateralism: an overview, in New Dimensions in Regional Integration, Jaime de Melo e Arvind Panagariya ed., Centre for Economic Policy Research, Cambridge University Press, 1993, p. 29.

${ }^{15}$ Sungjoon Cho, A Bridge Too Far: The Fall of the Fifth WTO Ministerial Conference in Cancun and the Future of Trade Constitution, in Journal of International Economic Law, vol. 7, n. ${ }^{0}$ 2, 2004, p. 237.

${ }^{16}$ Ainda que não se referindo especificamente aos países que giravam em torno da ex-URSS, Roberto Echandi observa que "other targets of government signals when negotiating Regional Trade Agreements are international financial institutions, Multinational Enterprises, and stock markets around the world. The negotiation of Regional Trade Agreements has often been used to demonstrate to this audience the commitment of governments to free trade and to consolidation of market-oriented reforms". Cf. Roberto Echandi, Regional Trade Integration in the Americas during the 1990s: Reflections of Some Trends and Their Implications for the Multilateral Trade System, in Journal of International Economic Law, 2001, p. 404.

${ }^{17}$ Richard Baldwin, The Causes of Regionalism, in The World Economy, 1997, pp. 865-888. No caso específico da Europa Ocidental, André Sapir nota que, "in 1960, the 16 trading countries of the region fell into three groups: the five trading members of the European Economic Community (EEC: Belgium-Luxembourg, France, Germany, Italy and the Netherlands); the seven members of the European Free Trade Association (EFTA: Austria, Denmark, Norway, Portugal, Sweden, Switzerland and the United Kingdom); and four countries belonging to neither the EEC nor the EFTA (Finland, Greece, Ireland and Spain). By 1995, the region had evolved into a large entity, the European Union (EU), comprising of fourteen trading countries. The other two countries of the region belonged to the EFTA, and were linked to the EU by means of separate preferential trading arrangements (the European Economic Area for Norway, and a more modest free-trade area in the case of Switzerland)". Cf. André Sapir, Domino effects in Western European regional trade, 1960-1992, in European Journal of Political Economy, 2001, p. 378. 
Pela simples razão de que, quando os países formam novos blocos econômicos regionais ou fortalecem os já existentes, as empresas dos países que ficam de fora vêem reduzidos os seus lucros (continuam sujeitas ao pagamento de direitos aduaneiros), pelo que, ao mesmo tempo que aumenta o desvio dos fluxos comerciais e de investimento impostos aos países excluídos, aumenta também o interesse (e a pressão) dos seus exportadores quanto à adesão a um bloco ${ }^{18}$. $\mathrm{O}$ caso da Comunidade Européia a suscitar pedidos de adesão de quase todos os países da Europa é plenamente elucidativo. O "efeito dominó do regionalismo" só não se verifica quando um país enfrenta resistências internas muito fortes quanto a uma eventual adesão (o caso da Noruega em relação à Comunidade Européia) ou quando a sua adesão implica para o bloco custos econômicos e políticos muito elevados (o caso da Turquia em relação à Comunidade Européia).

\section{A Exceção à Cláusula da Nação Mais Favorecida}

\subsection{A Cláusula da Nação Mais Favorecida}

No caso do GATT, a cláusula da nação mais favorecida encontra-se consagrada logo na sua primeira disposição e implica que:

"Qualquer vantagem, favor, privilégio ou imunidade concedida por [um Membro] a um produto originário de outro [Membro] será, imediata e incondicionalmente, extensiva a todos os produtos similares originários dos territórios de qualquer país ou a eles destinados. Esta disposição refere-se aos direitos aduaneiros

\footnotetext{
${ }^{18}$ Por exemplo, depois da entrada em funcionamento em 2001 da zona de comércio livre negociada com os EUA, as exportações da Jordânia para o mercado norte-americano passaram de 31 milhões de dólares Norte-americanos, em 1999, para 412 milhões de dólares em 2002 (cf. Daniel Griswold, Free-Trade Agreements: Steppingstones to a More Open World, CATO Institute Trade Briefing Paper n. ${ }^{0}$ 18, 10-7-2003, p. 12) e, no caso do México, a sua participação no NAFTA e noutros blocos econômicos regionais levou a que os fluxos de investimento direto estrangeiro passassem de 3.9 biliões de dólares entre 1990 e 1993 para 25 biliões de dólares em 2001 (cf. OMC, World Trade Report 2003, ed. OMC, 2003, p. 63). Mas, a respeito desta última situação, será que um bloco econômico regional "desvia” os fluxos de investimentos internacionais na direção dos países membros? Em traços gerais, quando se forma um bloco econômico regional, as empresas estabelecidas em países terceiros são estimuladas a implantar novas unidades de produção num país membro e, em consequiência, a abastecer os outros membros do bloco através de exportações realizadas no interior do próprio espaço de integração econômica. Na medida em que existam rendimentos de escala crescentes, a criação de um mercado maior, conjuntamente com um aumento da concorrência, fará baixar os custos de produção por unidade e tornará mais atractivo o estabelecimento na região. Também a aplicação de regras de origem restritivas pode constituir um incentivo adicional para haver "desvio de investimento".
} 
e às imposições de qualquer espécie que incidem sobre as importações ou exportações ou que são aplicadas por ocasião das importações ou exportaçōes, assim como às que incidem sobre as transferências internacionais de fundos destinados ao pagamento de importaçôes ou exportaçōes, ao modo de percepção destes direitos e imposições, a todas as regulamentaçôes e formalidades relativas às importaçōes e às exportações e a todas as questôes que são objeto dos no ${ }^{\circ} \mathrm{s} e$ 4 do artigo III" (art. I, no 1).

Em suma, é proibido a um Membro da OMC (País A) tratar mais favoravelmente os produtos originários de outro País em relação aos produtos similares originários de todos os outros Membros da OMC, pelo que, se vinte Membros da OMC exportarem bolas de futebol para o País A, este deve conceder o mesmo tratamento a todos os exportadores, cobrando, designadamente, um direito aduaneiro de valor igual a todos eles ${ }^{19}$.

Contudo, quando dois ou mais países se agrupam para constituir uma zona de comércio livre ou uma união aduaneira, eles eliminam os direitos aduaneiros e as restrições quantitativas nas trocas comerciais realizadas entre si, mas não nas trocas comerciais efetuadas com países terceiros. Por conseguinte, no caso desta importante exceção à

\footnotetext{
${ }^{19}$ Em relação à cláusula da nação mais favorecida do GATT, é de notar que estamos perante uma cláusula incondicional e automática, donde resulta que uma vantagem concedida por um Membro da 0MC a um país deve ser atribuída, imediata e incondicionalmente, a todos os outros Membros da OMC, não importando se estes cumprem ou não as condições impostas àquele país (cf. Relatório do Painel no caso Indonesia - Certain Measures Affecting the Automobile Industry, 2-7-1998, parágrafos 14.143-14.148). Além disso, a cláusula da nação mais favorecida aplica-se a todos os produtos e não apenas aos produtos consolidados nas listas de concessões referidas no art. II do GATT (cf. Relatório do Painel no caso Spain - Tariff Treatment of Unroasted Coffee, 11-6-1981, parágrafo 4.3). Por último, o n.. 1 do art. I do GATT cobre, não apenas a discriminação "formal" ou de jure, mas também a discriminação "material" ou de fato (cf. Relatório do Órgão de Recurso no caso Canada - Certain Measures Affecting the Automotive Industry, 31-5-2000, parágrafo 78). No caso Canada - Certain Measures Affecting the Automotive Industry, o Órgão de Recurso concluiu que um conjunto de medidas aplicadas pelo Canadá (Pauta Aduaneira, ordem pautal relativa a veículos de motor de 1998 (Motor Vehicles Tariff Order) e ordens especiais de remissão (Special Remission Orders)), as quais limitavam a isenção do pagamento de direitos aduaneiros a certos fabricantes, constituía uma violação de fato da cláusula da nação mais favorecida, não obstante as medidas em causa serem neutras quanto à origem dos produtos importados. É que, embora as medidas em causa não impusessem, à primeira vista, qualquer restrição formal quanto à origem do veículo automóvel importado, a limitação a determinados importadores da possibilidade de beneficiar da isenção de direitos aduaneiros, conjugada com o fato de o comércio de produtos da indústria automóvel se efetuar freqüentemente entre empresas do mesmo grupo, implicava que a isenção do pagamento de direitos aduaneiros aplicada pelo Canadá iria beneficiar, muito provavelmente, as importações originárias dos EUA.
} 
cláusula da nação mais favorecida (art. XXIV, $\mathrm{n}^{\circ} \mathrm{s} 4$ a 10, do GATT) ${ }^{20}$, a preocupação essencial passa por exigir que a criação de uma união aduaneira ou de uma zona de comércio livre tenha "por objetivo facilitar o comércio entre os territórios constitutivos e não opor obstáculos ao comércio de outros membros com estes territórios" (art. XXIV, n ${ }^{\circ}$ 4, in fine, do GATT) ${ }^{21}$.

\subsection{O Artigo XXIV, nºs 4 a 10, do GATT}

Para que um bloco econômico regional possa ser considerado uma exceção legítima à cláusula da nação mais favorecida, o art. XXIV do GATT impõe a observância dos seguintes critérios:

\section{a) O Critério do "Essencial das Trocas Comerciais"}

Nos termos do $\mathrm{n}^{\circ} 8$ do art. XXIV do GATT, "os direitos aduaneiros e as outras regulamentações comerciais restritivas devem ser eliminados para o essencial das trocas

\footnotetext{
${ }^{20}$ De todas as formas teoricamente possíveis de integração econômica regional, o GATT, lidando somente com mercadorias, só se refere à zona de comércio livre e à união aduaneira, embora no art. XXIV, n. ${ }^{0} 7$, alíneac), se afirme a possibilidade de acompanhamento da evolução dos processos de integração econômica regional. Outra razão para o GATT não se referir a outras formas de integração regional prende-se com o fato de o art. XXIV do GATT ter sido redigido $\log 0$ a seguir ao final do segundo conflito mundial, quando ainda não eram previsíveis outras formas de integração, pelo menos não enquanto ameaça ao sistema comercial multilateral (cf. Peter Hilpold, Regional Integration According to Article XXIV GATT - Between Law and Politics, in Max Planck Yearbook of United Nations Law, vol. 7, 2003, p. 227). Atualmente, se fizermos uma tipologia da chamada integração econômica institucional (por contraposição à chamada integração econômica espontânea), verificamos que ela abarca os seguintes estádios: - Zona de comércio livre: comporta a livre circulação de mercadorias, sem imposição de restrições quantitativas e de direitos aduaneiros no comércio entre os países membros da zona. Cada país membro mantém, todavia, uma pauta aduaneira própria em relação aos países não membros, pelo que não existe uma pauta aduaneira comum aplicável a países terceiros. Assim sendo, os direitos aduaneiros diferem geralmente de um membro para outro, pelo que os exportadores situados num país terceiro, por vezes, têm interesse em entrar na zona através do mercado do membro que tem os direitos aduaneiros mais reduzidos (é o chamado "efeito deflector do comércio", que só se verificase os custos de transporte forem inferiores à diferença entre as tarifas aduaneiras dos países em causa). Para evitar que tal aconteça, os membros da zona adotam regras de origem, destinadas a determinar se as mercadorias que entram num país membro da zona de comércio livre foram produzidas ou não no seu interior. Só as mercadorias originárias da zona de comércio livre não pagarão direitos aduaneiros. Exemplo de zona de comércio livre é a Associação Européia de Comércio Livre, limitada, em princípio, aos produtos industriais, por causa das particularidades do processo de produção dos produtos agrícolas (a sua dependência do meio-ambiente, podendo as variações climáticas provocar fortes diferenças dum ano para outro nos volumes de produção, o que contribui decisivamente para as flutuações de preços); - União aduaneira: além da livre circulação de mercadorias, existe uma pauta
} 
comerciais". Trata-se aqui, sobretudo, de interpretar corretamente a expressão "o essencial das trocas comerciais". Saber se a expressão deve ser interpretada em termos qualitativos (inclusão dos principais setores de atividade econômica), e/ou em termos quantitativos (o volume de comércio intra-regional a abranger por um bloco).

aduaneira comum, aplicável em todas as fronteiras da união aduaneira. Por isso se diz que, no caso da zona de comércio livre, a unificação é interna, ao passo que na união aduaneira a unificação é não só interna, mas também externa. E a fim de não se beneficiar um país pelo simples fato de possuir melhores vias de comunicação ou condições para ser entreposto de entrada de produtos (o chamado efeito de Antuérpia-Roterdão), os direitos aduaneiros constituem, geralmente, receitas próprias da união, sendo cobrados pelos Estados-membros em seu nome. Uma união aduaneira comporta, enfim, a adoção de uma política comercial comum face a países terceiros ou, pelo menos, uma certa coordenação de posições nos fóruns internacionais; - Mercado comum: a noção de mercado comum abarca a de união aduaneira, mas, além disso, implica a livre circulação de trabalhadores, a liberdade de estabelecimento de produtores e comerciantes, a livre prestação de serviços, a livre circulação de capitais, a adoção de algumas políticas comuns e a harmonização das legislações nacionais indispensáveis à existência de um mercado único; União econômica: segundo o Relatório Delors de 1989, relatório que teve um papel fundamental no processo de introdução de uma moeda única no espaço comunitário depois consagrado no Tratado de Maastricht, uma "união econômica pode ser descrita através de quatro elementos básicos: um mercado único, onde podem circular livremente pessoas, mercadorias, serviços e capitais; uma política de concorrência e outras medidas com vista ao reforço dos mecanismos de mercado; políticas comuns com vista a mudanças estruturais e ao desenvolvimento regional; e a coordenação da política macro-econômica, incluindo regras vinculativas para as políticas orçamentais" (considerando 25); - União monetária: segundo o mesmo Relatório Delors, "há três condições necessárias para a união monetária: a garantia de uma convertibilidade total e irreversível das moedas; a liberalização completa das transações de capitais e a total integração da atividade bancária e de outros mercados financeiros; e a eliminação das margens de flutuação e a fixação definitiva das paridades das taxas de câmbio" (considerando 22). A adoção de uma moeda única, embora não seja indispensável à criação de uma união monetária, é considerada, por razões psicológicas, políticas e econômicas, como um desenvolvimento natural e desejável. Uma moeda única demonstra, claramente, a irreversibilidade do processo de realização da união monetária e facilita, significativamente, a gestão da política monetária. É de notar também que alguns blocos econômicos regionais comportam características que os tornam algo híbridos. Por exemplo, no caso do NAFTA, estamos perante uma zona de comércio livre atípica: as regras do Acordo aplicam-se a mercadorias, serviços e capitais e não existe nenhuma pauta aduaneira comum.

${ }^{21}$ Para o Órgão de Recurso, "o n. ${ }^{0} 4$ está redigido em termos programáticos e não imperativos. Ele não enuncia uma obrigação autônoma propriamente dita, mas sim o fim primeiro omnipresente do artigo XXIV, o qual se manifesta através dos termos imperativos utilizados para estipular as obrigações específicas que constam de outras partes do mesmo artigo. Assim, o fim enunciado no n. ${ }^{\circ} 4$ influencia os outros números pertinentes do artigo XXIV, incluindo o prólogo do n. ${ }^{\circ}$ 5. Por este motivo, o prólogo do n. ${ }^{\circ} 5$ e as condições aí enunciadas para a possibilidade de recorrer a uma defesa baseada no artigo XXIV devem ser interpretados à luz da finalidade das uniões aduaneiras indicada no n. ${ }^{0}$ 4. Não é possível interpretar corretamente o texto introdutório sem fazer constantemente referência àquele fim". Cf. Relatório do Órgão de Recurso no caso Turkey - Restrictions on Imports of Textile and Clothing Products, 22-10-1999, parágrafo 57. 
Quando em 1960 a Convenção de Estocolmo foi submetida a exame, nos termos do no 7 do art. XXIV do GATT, os Estados-membros da Associação Européia de Comércio Livre (mais conhecida pela sigla inglesa EFTA), declararam que a zona de comércio livre cobriria, pelo menos, cerca de $90 \%$ do comércio da zona, respeitando, conseqüentemente, o requisito da essencialidade ${ }^{22}$. Todavia, o relatório do grupo de trabalho responsável pelo exame da Convenção de Estocolmo chamou a atenção para o fato de esta não abarcar os produtos agrícolas e piscícolas e que:

"a frase 'o essencial das trocas comerciais' tinha um aspecto qualitativo e um aspecto quantitativo e, por isso, não poderia ser vista como permitindo a exclusão de um setor de atividade econômica importante" ${ }^{, 23}$.

Pouco esclarecedor é o preâmbulo do Memorando de Entendimento sobre a Interpretação do Artigo XXIV do Acordo Geral sobre Pautas Aduaneiras e Comércio de 1994 adotado no Ciclo do Uruguai, visto se limitar a reconhecer:

"que uma integração mais profunda das economias das partes nesses acordos [uniōes aduaneiras e zonas de comércio livre] pode contribuir para a expansão do comércio mundial" (considerando 30); e

"que essa contribuição é maior se a eliminação dos direitos aduaneiros e de outras regulamentaçôes comerciais restritivas entre os territórios constitutivos se alargar a todo o comércio e menos se um setor importante de comércio for excluído" (considerando $4^{\circ}$ ).

Pouco esclarecedora é igualmente a seguinte conclusão do Órgão de Recurso da OMC: "nem as PARTES CONTRATANTES do GATT nem os membros da OMC alguma vez se entenderam quanto à interpretação do termo 'essencial' constante desta disposição. É, contudo, evidente que 'o essencial das trocas comerciais' não é a mesma coisa que a totalidade das trocas comerciais, e que 'o essencial das trocas' é algo mais importante do que apenas uma certa parte das trocas" ${ }^{24}$.

\footnotetext{
${ }^{22}$ Victoria Curzon, The Essentials of Economic Integration. Lessons of EFTA Experience, Macmillan, Londres, 1974 , p. 86.

${ }^{23}$ GATT, Analytical Index ..., p. 767.

${ }^{24}$ Relatório do Órgão de Recurso no caso Turkey - Restrictions on Imports of Textile and Clotbing Products, 22-10-1999, parágrafo 48.
} 
Em nossa opinião, muito embora o aspecto quantitativo e o aspecto qualitativo se encontrem necessariamente interrelacionados, podem ser avançados diversos argumentos a favor de uma interpretação mais próxima do primeiro aspecto que do segundo. Primeiro, os grupos de trabalho criados posteriormente não confirmaram a opinião do grupo de trabalho que examinou a Convenção de Estocolmo ${ }^{25}$. Segundo, os trabalhos preparatórios fornecem um argumento a favor da exclusão de alguns setores do requisito "o essencial das trocas comerciais" ${ }^{26}$. Terceiro, o art. V, no 1 , alínea a), do GATS, ao estabelecer que o acordo de liberalização do comércio de serviços deve ter uma cobertura setorial significativa, em termos de número de setores, volume de comércio afetado e modos de prestação, torna claro que nem todos os setores precisam de ser incluídos ${ }^{27}$. Quarto, o próprio preâmbulo do Memorando de Entendimento sobre a Interpretação do Artigo XXIV do Acordo Geral sobre Pautas Aduaneiras e Comércio de 1994 parece não afastar a hipótese de exclusão de um setor importante do comércio ${ }^{28}$. Finalmente, a realidade mostra que a maioria dos blocos econômicos regionais exclui a agricultura do âmbito da liberalização comercial levada a cabo entre os países que neles participam ${ }^{29}$.

\footnotetext{
${ }^{25}$ Rodolphe Imhoof, Le GATT et les zones de libre-échange, Imprimerie Courvoisier S.A., 1979, p. 70.

${ }^{26}$ Robert E. Hudec e James D. Southwick, Regionalism and WTO Rules: Problems in the Fine Art of Discriminating Fairly, in Trade Rules in the Making: Challenges in Regional and Multilateral Negotiations, Miguel Rodríguez Mendoza, Patrick Low e Barbara Kotschwar ed., Organization of American States-Brookings Institution Press, Washington, D.C., 1999, p. 62.

${ }^{27}$ Segundo o Órgão de Recurso, "à luz do princípio do efeito útil, o intérprete de um tratado está obrigado 'a ler todas as disposições aplicáveis de um tratado de maneira a dar sentido a todas elas, harmoniosamente'. Um corolário importante deste princípio é o de que é necessário interpretar um tratado como um todo e, em particular, ler as suas seções e partes como um todo. 0 artigo II, n. ${ }^{\circ}$ 2, do Acordo OMC manifesta a intenção dos negociadores do Ciclo do Uruguai de as disposições do Acordo OMC e dos acordos comerciais multilaterais incluídos nos seus Anexos 1, 2 e 3 serem lidas como um todo". Cf. Relatório do Órgão de Recurso no caso Korea - Definitive Safeguard Measure on Imports of Certain Dairy Products, 14-12-1999, parágrafo 81.

${ }^{28} 0$ preâmbulo do Memorando alerta apenas para o fato de ser menor a contribuição das uniões aduaneiras e zonas de comércio livre para a expansão do comércio mundial se um setor importante de comércio for excluído. Já Won-Mog Choi entende que "it can be said that the exclusion of a certain major sector, especially agriculture, could arguably make the RTA inconsistent with the internal requirement of GATT Article XXIV". Cf. Won-Mog Choi, Regional Economic Integration in East Asia: Prospect and Jurisprudence, in Journal of International Economic Law, 2003, p. 64.

${ }^{29}$ OMC, Coverage, Liberalization Process and Transitional Provisions in Regional Trade Agreements, Background survey by the Secretariat, 5-4-2002, parágrafo 59.
} 
Por não respeitar, de todo, o critério do "essencial das trocas comerciais", a Comunidade Européia do Carvão e do Aço foi autorizada por uma derrogação concedida em 1952, nos termos do art. XXV, no 5, do GATT. Da mesma forma, os EUA obtiveram, em 1965, uma derrogação para o acordo concluído com o Canadá relativo ao livre comércio de produtos do setor automóvel.

Ainda em relação ao critério do "essencial das trocas comerciais", resulta do no 8 do art. XXIV que os membros dos blocos econômicos regionais podem manter nas trocas comerciais realizadas entre si, na medida em que tal seja necessário, restrições autorizadas nos termos dos artigos XI, XII, XIII, XIV, XV e XX do GATT. E ao abrigo de outras disposições, não referidas, como, por exemplo, o art. XXI, alínea $b$ )(III)? A resposta só pode ser positiva, visto que, segundo esta disposição:

"nenhuma disposição do Acordo Geral será interpretada (...) como impedindo um membro de tomar todas as medidas que julgue necessárias à proteção dos interesses essenciais da sua segurança (...) aplicadas em tempo de guerra ou em caso de grave tensão internacional" (itálico aditado).

Nem sequer se estabelece, como acontece com o art. XX do GATT, que as medidas a tomar não devem ser aplicadas de forma a constituir um meio de discriminação arbitrária ou injustificada entre os países onde existam as mesmas condições ou uma restrição disfarçada ao comércio internacional. Apenas se diz que o país em causa deve estar em guerra ou perante um caso de grave tensão internacional, situações que lhe permitem tomar unilateralmente todas as medidas que julgue necessárias à proteção dos interesses essenciais da sua segurança ${ }^{30}$. Note-se, por outro lado, que o Acordo Geral sobre o

\footnotetext{
${ }^{30}$ Há pouco tempo, por exemplo, os EUA justificaram a chamada Lei Helms-Burton, afirmando que se tratava, nos termos do art. XXI do GATT, de uma questão de "segurança nacional", prerrogativa elementar de qualquer Estado enquanto comunidade politicamente organizada. A adoção em 1996 da chamada Lei da Liberdade e da Solidariedade com Cuba, mais conhecida por Lei Helms-Burton, tinha por objetivo reforçar e internacionalizar o isolamento de Cuba, impondo unilateralmente o embargo econômico norte-americano ao resto do Mundo. Assim, a fim de reforçar as sanções econômicas contra Cuba e punir as empresas com interesses econômicos neste país, a Lei Helms-Burton permitia aos cidadãos norte-americanos apresentar queixas nos tribunais norte-americanos contra as empresas estrangeiras que utilizassem em Cuba os bens de nacionalidade americana confiscados depois da revolução (Título III) e proibir a entrada nos EUA aos seus gestores, familiares dos gestores e acionistas (Título IV). Mas, no caso da lei norte-americana, o que é interessante verificar é o fato de os EUA oferecerem dois pesos e duas medidas, conforme os seus interesses diretos. É que, se relativamente à China, um mercado potencial de mais de um bilião de consumidores, certos políticos norte-americanos advogam que a ajuda ao desenvolvimento econômico poderá servir para reforçar as tendências democráticas, (desde 1980 até à adesão da China à OMC, os EUA renovaram anualmente à China o estatuto de "nação mais favorecida"), independentemente da
} 
Comércio de Serviços reconhece expressamente que as excepçōes por razões de segurança podem constituir uma exceção à regra da ausência ou da eliminação em termos substanciais de todo o tipo de discriminação (art. V, no 1 , alínea b).

Muito discutível era também o fato de alguns membros de um bloco econômico regional, quando recorriam à cláusula de salvaguarda geral do art. XIX do GATT, não aplicarem as medidas aí previstas aos outros membros do bloco, independentemente do prejuízo grave poder ser causado ou não pelas suas exportaçôes ${ }^{31}$. John Jackson, por exemplo, considerava que tal comportamento, ainda que discutível, era admissível, "since the preferential group should be treated more like a single trading entity" ${ }^{32}$.

Neste caso, o Órgão de Recurso considera que resulta da redação dos dois números do art. $2^{\circ}$ do Acordo sobre as Medidas de Salvaguarda o denominado princípio ou conceito do paralelismo ${ }^{33}$ :

"Artigo 2o

Condiçôes

1 - Um Membro ${ }^{34}$ poderá aplicar uma medida de salvaguarda em relação a um produto unicamente se tiver determinado, em conformidade com as disposições

repressão e da violação sistemática dos direitos humanos, já relativamente a Cuba parecem adoptar outra atitude, diametralmente oposta. Além disso, a expropriação e nacionalização por Cuba, sem indemnização, dos bens de cidadãos norte-americanos dificilmente pode ser considerada como pondo em causa os interesses essenciais da segurança dos EUA ou provocando uma situação de grave tensão internacional, principalmente quando se trata de um fato ocorrido entre 1959 e 1961. Como se isso não bastasse, não só o Conselho de Segurança das Nações Unidas não adoptou nenhuma resolução contra Cuba, elemento que indicia a inexistência de uma situação de grave tensão internacional (cf. Kees Jan Kuilwijk, Castro's Cuba and the U.S. Helms-Burton Act:An Interpretation of the GATT Security Exemption, in Journal of World Trade, 1997, p. 54), como a própria Assembleia Geral votou, em Novembro de 1992, contra o embargo imposto pelos EUA (Resolução 47/19). De qualquer modo, por causa da polêmica que suscitou, a aplicação do Título III da Lei Helms-Burton ("Proteção dos Direitos de Propriedade de Cidadãos dos Estados Unidos") tem sido sucessivamente suspensa por decisão do Presidente dos Estados Unidos. 0 texto da Lei Helms-Burton pode ser encontrado in International Legal Materials, vol. XXXV, 1996, pp. 357-378. ${ }^{31}$ Aliás, uma vez que as trocas comerciais realizadas com os outros países participantes no bloco econômico regional não se encontram sujeitas ao pagamento de direitos aduaneiros, o mais provável é que a causa do prejuízo grave se encontre mais nessas trocas do que nas trocas realizadas com os outros membros da OMC.

${ }_{33}^{32}$ John Jackson, Regional Trade Blocs and the GATT, in The World Economy, 1993, p. 126.

${ }^{33}$ Relatório do Órgão de Recurso no caso United States - Definitive Safeguard Measures on Imports of Circular Welded Carbon Quality Line Pipe from Korea, 15-2-2002, parágrafo 179.

34 "Uma união aduaneira poderá aplicar uma medida de salvaguarda enquanto entidade única ou em nome de um Estado membro. Quando uma união aduaneira aplicar uma medida de salvaguarda enquanto entidade, todos os requisitos para a determinação da existência de um prejuízo grave ou de uma ameaça de prejuízo grave 
a seguir enunciadas, que esse produto é importado no seu território em quantidades de tal modo elevadas, em termos absolutos ou em relação à produção nacional, e em tais condiçóes que cause ou ameace causar um prejuízo grave ao ramo de produção nacional de produtos similares ou directamente concorrentes.

2 - As medidas de salvaguarda serão aplicadas a um produto importado independentemente da sua origem".

No caso United States - Definitive Safeguard Measures on Imports of Wheat Gluten from the European Communities, o Órgão de Recurso observou que:

“a mesma frase - 'produto importado' - figura em ambos os números do artigo 2. Tendo em conta que se utilizou a mesma linguagem nas duas disposições, e na ausência de qualquer indicação em contrário no contexto, acreditamos que é apropriado atribuir o mesmo sentido a esta frase tanto no $\mathrm{n}^{\circ} 1$ como no $\mathrm{n}^{\circ} 2$ do artigo $2^{\circ}$. Incluir as importações procedentes de todas as fontes na determinação de que o aumento das importações está a causar um prejuízo grave, e depois excluir as importações procedentes de uma fonte do âmbito de aplicação da medida, significaria dar à frase 'produto importado' um sentido diferente nos $n^{\circ} s$ 1 e 2 do artigo $2^{\circ}$ do Acordo sobre as Medidas de Salvaguarda. No no 1 do artigo $2^{\circ}$ a frase abarcaria as importações procedentes de todas as fontes, ao passo que, no $n^{\circ} 2$ do artigo $2^{\circ}$, seriam excluídas as importações de determinadas fontes. Isto seria incongruente e injustificado. Consequentemente, as importações incluídas nas determinaçōes feitas ao abrigo dos artigos $2^{\circ}, n^{\circ} 1$, e $4^{\circ}, n^{\circ} 2$, [do Acordo sobre as Medidas de Salvaguarda] deveriam corresponder às importaçóes compreendidas no âmbito de aplicação da medida, ao abrigo do art. $2^{\circ}, \mathrm{n}^{\circ} 2$, [do Acordo sobre as Medidas de Salvaguarda]"35.

Assim, o princípio do paralelismo é violado se um Membro da OMC toma em consideração todas as importações na determinação do prejuízo grave, mas depois exclui as importações dos seus parceiros no bloco econômico regional do âmbito da medida de salvaguarda aplicada. Exemplo disso é o caso Argentina-Safeguard Measures on Imports of Footwear:

a título do presente Acordo deverão basear-se nas condições existentes no conjunto da união aduaneira. Quando uma medida de salvaguarda for aplicada em nome de um Estado membro, todos os requisitos para a determinação da existência de um prejuízo grave ou de uma ameaça de prejuízo grave deverão basear-se nas condições existentes nesse Estado membro e a medida limitar-se a esse Estado membro. Nenhuma disposição do presente Acordo prejudica a interpretação da relação entre o artigo XIX e o n. 8 do artigo XXIV do GATT de 1994".

${ }^{35}$ Relatório do Órgão de Recurso no caso United States - Definitive Safeguard Measures on Imports of Wheat Gluten from the European Communities, 22-12-2000, parágrafo 96. 
“a investigação realizada pela Argentina, que avaliou se um prejuízo grave ou uma ameaça de prejuízo grave era causado pelas importações originárias de todas as fontes, só podia dar lugar à aplicação de medidas de salvaguarda às importações originárias de todas as fontes. Por conseguinte, concluímos que a investigação realizada pela Argentina neste caso não pode servir de base à exclusão das importações originárias de outros Estados membros do MERCOSUL da aplicação das medidas de salvaguarda. Pelas razões expostas, revogamos as constatações e conclusões do Painel relativas à nota de rodapé 1 do $n^{\circ} 1$ do artigo $2^{\circ}$ do Acordo sobre as Medidas de Salvaguarda e ao artigo XXIV do GATT de 1994. Concluímos que a Argentina não pode justificar, tendo em conta os fatos do caso em exame, a aplicação das suas medidas de salvaguarda unicamente às fontes de abastecimento de países terceiros que não são membros do MERCOSUL baseando-se numa investigação que constatou a existência ou ameaça de prejuízo grave causado por importações originárias de todas as fontes, incluindo as importações originárias de outros Estados membros do MERCOSUL”"

\section{Mais recentemente, o Órgão de Recurso declarou que:}

"a questão de saber se o artigo XXIV do GATT 1994 serve como exceção ao no 2 do artigo $2^{\circ}$ do Acordo sobre as Medidas de Salvaguarda só se torna pertinente em duas possíveis circunstâncias. Uma é quando na investigação realizada pelas autoridades competentes de um Membro da OMC as importações que estão excluídas da medida de salvaguarda não são tomadas em consideração na determinação do prejuízo grave. A outra é quando, nessa investigação, as importações que estão excluídas da aplicação da medida de salvaguarda são tomadas em consideração na determinação do prejuízo grave $e$ as autoridades competentes também estabeleceram expressamente, mediante uma explicação fundamentada e apropriada, que as importaçóes originárias de fontes externas à zona de comércio livre, sozinhas, satisfazem as condiçôes para a aplicação de uma medida de salvaguarda, conforme o estabelecido no $\mathrm{n}^{\circ} 1$ do artigo $2^{\circ}$ e desenvolvido no $\mathrm{n}^{\circ} 2$ do artigo $4^{\circ}$ [do Acordo sobre as Medidas de Salvaguarda]" ${ }^{37}$.

\footnotetext{
${ }^{36}$ Relatório do Órgão de Recurso no caso Argentina - Safeguard Measures on Imports of Footwear, 14-121999, parágrafos 113-114.

${ }^{37}$ Relatório do Órgão de Recurso no caso United States - Definitive Safeguard Measures on Imports of Circular Welded Carbon Quality Line Pipe from Korea, 15-2-2002, parágrafo 198.
} 
Acertada é, em nosso entender, a seguinte opinião de Joost Pauwelyn:

"under WTO rules, (...) a safeguard limited to regional imports only would clearly violate the non-discrimination provision of Article 2.2 of the Agreement on Safeguards. Moreover, such exclusion of third-party imports cannot be justified under GATT Article XXIV: imposing more trade restrictions on regional partners than on third parties is antithetical to regional free trade" ${ }^{, 38}$.

Por último, não podemos deixar de chamar atenção para o fato de, à primeira vista, o critério do "essencial das trocas comerciais" parecer algo incongruente. De fato, ao exigir que a discriminação em favor dos parceiros do bloco econômico regional abarque o "essencial das trocas comerciais", o GATT não aceita pequenos desvios à pedra angular do sistema comercial multilateral: a cláusula da nação mais favorecida. Sucede que o critério visa ajudar os governos a resistir às pressóes exercidas sobre eles para que não eliminem os direitos aduaneiros que protegem os setores menos capazes de enfrentar a concorrência de outros países, ou seja, se os países pudessem escolher livremente os setores a incluir num bloco econômico regional, muito provavelmente só seriam incluídos os setores mais propensos à ocorrência do efeito de "desvio de comércio". Frieder Roessler observa ainda que:

"preferential arrangements covering a small portion of trade are unlikely to have as strong a political support. The substantially-all-trade requirement can, therefore, be seen as a requirement that helps differentiate between politically unavoidable and containable deviations from the most-favoured-nation principle, as a requirement which determines the point where trade policy is allowed to give way to foreign policy ${ }^{39}$.

\section{b) O Critério Relativo ao Comércio Externo}

O outro critério de fundo é o que consta do $\mathrm{n}^{\circ}$, alíneas $a$ ) e $b$ ), do art. XXIV do GATT. No caso das uniōes aduaneiras, a alínea $a$ ) determina que:

"os direitos aduaneiros e outras regulamentaçôes comerciais aplicados, quando do estabelecimento da união ou da conclusão do acordo provisório, ao comércio com os territórios dos membros que não forem partes em tal união ou acordo, não devem ser, no seu conjunto, mais elevados ou mais restritivos do que a

\footnotetext{
${ }^{38}$ Joost Pauwelyn, The Puzzle of WTO Safeguards and Regional Trade Agreements, in Journal of International Economic Law, 2004, p. 126.

${ }^{39}$ Frieder Roessler, The Relationship Between Regional Trade Agreements and the Multilateral Trade Order: A Reassessment, in The Legal Structure, Functions \& Limits of the World Trade Order-A Collection of Essays by Frieder Roessler, Cameron May, Londres, 2000, p. 184.
} 
incidência geral dos direitos e regulamentaçōes comerciais aplicáveis nos territórios constitutivos da união antes do estabelecimento desta ou da conclusão do acordo provisório consoante o caso".

Analogamente, no caso de uma zona de comércio livre, a alínea $b$ ) impõe que os direitos aduaneiros e outras regulamentaçôes comerciais mantidos em cada um dos territórios que a constituem não devem ser mais elevados ou mais restritivos do que os correspondentes direitos e outras regulamentaçōes comerciais em vigor nos mesmos territórios constitutivos antes do seu estabelecimento ou da conclusão do acordo provisório, consoante o caso ${ }^{40}$.

A respeito deste critério, o Memorando de Entendimento sobre a Interpretação do Artigo XXIV do GATT de 1994 resolveu algumas das suas maiores dificuldades de interpretação. Por exemplo, no que diz respeito ao cálculo da incidência geral dos direitos aduaneiros no caso das uniões aduaneiras ${ }^{41}$, o Memorando estabelece que:

“a avaliação prevista no $\mathrm{n}^{\circ} 5$, alínea $a$ ), do art. XXIV, da incidência geral dos direitos aduaneiros e de outras regulamentaçōes comerciais aplicáveis antes e após o estabelecimento de uma união aduaneira basear-se-á, no que diz respeito aos direitos aduaneiros e às imposiçoes, numa avaliação global das taxas médias ponderadas dos direitos e nos direitos aduaneiros cobrados. Essa avaliação basear-se-á nas estatísticas

\footnotetext{
${ }^{40}$ No caso das zonas de comércio livre, é de atentar no fato de o n. ${ }^{\circ} 5$, alínea $b$ ), do art. XXIV utilizar as palavras "correspondentes direitos", o que é bem diferente das palavras "incidência geral" utilizadas na alínea $a$ ) do mesmo número, a propósito das uniões aduaneiras, e daí Won-Mog Choi concluir que "it is difficult to deny that the product-by-product assessment is required under article XXIV:5(b)". Cf. Won-Mog Choi, Regional Economic Integration in East Asia ..., p. 59.

${ }^{41}$ Quando o Tratado de Roma entrou em vigor, as pautas aduaneiras dos Estados-membros divergiam sensivelmente, sendo as da França e Itália, em geral, mais elevadas que as do Benelux e da Alemanha. Ora, para 0 estabelecimento da pauta aduaneira comum, o art. 19. ${ }^{\circ}$ do Tratado de Roma previa que os direitos da Pauta Aduaneira Comum se estabelecessem ao nível da média aritmética dos direitos aduaneiros aplicados, por produto, nos quatro territórios aduaneiros que então compunham a Comunidade Econômica Européia (o Benelux constituía então um território aduaneiro único), o que não deixou de suscitar críticas por parte de outras partes contratantes do GATT. 0 argumento avançado era o seguinte: se o direito aduaneiro francês para um determinado produto é de $10 \%$ e o direito alemão de $6 \%$, e se a média aritmética retida para a pauta aduaneira comum é de $8 \%$, um país terceiro que exporte bastante para a Alemanha, mas pouco para a França, verá a sua situação deteriorar-se. As críticas acabaram, porém, por se atenuar quando os seis Estados fundadores da Comunidade Econômica Européia decidiram, durante o Ciclo de Dillon, reduzir em 20\% os direitos aduaneiros sobre muitos produtos industriais. Cf. Richard Pomfret, The Economics of Regional Trading Arrangements, Clarendon Press, Oxford, 1997, p. 91.
} 
de importação relativas a um período representativo anterior, que serão comunicadas pela união aduaneira, por linha pautal, em valor e em volume, discriminadas por país de origem membro da Organização Mundial do Comércio. O Secretariado calculará as taxas médias ponderadas dos direitos e dos direitos aduaneiros cobrados segundo a metodologia utilizada na avaliação das ofertas pautais efetuadas no âmbito das negociaçōes comerciais do Ciclo do Uruguai. Para o efeito, os direitos aduaneiros e as imposiçốes a ter em conta serão as taxas dos direitos aplicados" (parágrafo $2^{\circ}{ }^{42}$.

Aparentemente, porém, nem tudo parece ter sido clarificado. Alguns autores perguntam, por exemplo, se é necessário que as taxas médias ponderadas atendam ao direito aduaneiro aplicado produto a produto ou será que é possível que um aumento do direito aduaneiro aplicado a um produto agrícola seja compensado por uma diminuição do direito aplicado a um produto manufacturado? A União Européia, por exemplo, defende que, face ao seu alargamento a outros países europeus, o aumento inevitável de barreiras comerciais discriminatórias em certas áreas, tais como a agricultura e os têxteis, pode ser compensado pela liberalização comercial registada noutros setores ${ }^{43}$.

Na opinião de Sungjoon Cho:

"this 'balancing' idea, which recognizes a trade-off between violations and the benefits to which they give rise, has been consistently rejected by the GATT/ WTO jurisprudence. A violation is a violation: it cannot be excused by any circumstance other than a formal exception. Indeed, if it still prevailed today, the European Union's position would create severe trade diversion, particularly for agricultural products and textiles, as it continues to enlarge" ${ }^{44}$.

\footnotetext{
${ }^{42}$ Segundo o Órgão de Recurso, "como o Painel, entendemos que os termos da alínea $a$ ) do n. ${ }^{\circ} 5$ do artigo XXIV, desenvolvidos e clarificados pelo parágrafo $2 .^{\circ}$ do Memorando de Entendimento sobre a Interpretação do Artigo XXIV do GATT de 1994, impõem que 'as medidas e políticas comerciais resultantes do novo acordo regional não terão efeitos globalmente mais restritivos sobre o comércio do que os das políticas comerciais anteriores dos países constitutivos" e concordamos ainda que se trata "de um critério 'econômico' a aplicar para determinar se uma determinada união aduaneira é compatível com o artigo XXIV”. Cf. Relatório do Órgão de Recurso no caso Turkey - Restrictions on Imports of Textile and Clothing Products, 22-10-1999, parágrafo 55.

${ }^{43}$ Sungjoon Cho, Breaking the Barrier Between Regionalism and Multilateralism: A New Perspective on Trade Regionalism, in Harvard International Law Journal, 2001, p. 441.

${ }^{44}$ Sungjoon Cho, Breaking the Barrier Between Regionalism and Multilateralism ..., p. 441.
} 


\section{Mais flexível é o entendimento de Won-Mog Choi:}

"to require that parties to a Customs Union should not raise average duty rates in respect of any tariff-line, and of the trade of any individual non-party, results in too strict a discipline upon Customs Unions. Moreover, this requirement does not harmonize with the flexible language 'on the whole' and with the drafting records, which suggested flexible understanding of the 'general incidence" ${ }^{\prime 45}$.

Ainda segundo o mesmo autor,

"opponents of this view might be concerned about trade diversions engendered by the cross-sector balancing: for example, many Customs Unions might try to raise tariffs on agricultural products while lowering tariffs on manufactured goods. But it should be noted that the rise cannot be substantial because of the limitation of the 'bound' rate of duty; raising beyond this limitation, the party has to go through the renegotiation procedure. Hence, it is not likely that allowing cross-sector balancing would cause significant trade diversion. Indeed, the words 'overall assessment' can be understood to mean such a cross-sector calculation of duties. Therefore, the external requirement for Customs Unions could be rephrased as follows: tradeweighted applied rates of duties, which are averaged among members as well as all product sectors, must not become higher at the formation of Customs Unions" ${ }^{\text {"46 }}$.

Outra dificuldade de interpretação importante tinha a ver com os direitos a ter em conta no estabelecimento de uma pauta aduaneira comum. De fato, antes da entrada em vigor dos acordos da OMC, as partes num acordo, quando negociavam um determinado tratamento pautal, podiam referir-se aos direitos consolidados nas respectivas listas de concessóes ou aos direitos efetivamente cobrados (no cálculo da pauta aduaneira comum dos seis Estados-membros originários da Comunidade Econômica Européia, por exemplo, utilizaram-se os direitos aduaneiros italianos consolidados, apesar de nunca terem sido aplicados $^{47}$ ). Acontece que, quando o valor de ambos não coincide, os direitos efetivamente

\footnotetext{
${ }^{45}$ Won-Mog Choi, Regional Economic Integration in East Asia ..., p. 58. Won-Mog Choi nota, ainda, que "opposing this logic, critics might indicate that another way to achieve the 'balancing' could be the balancing between the constituent parties in the same sector and that paragraphs 4 and 5 presuppose only that way of balancing". Cf. Idem.

Ibidem, pp. 58-59.

${ }^{47}$ Nigel Nagarajan, Regionalism and the WTO: New Rules for the Game?, in Economic Papers n. ${ }^{\circ} 128,1998$, p. 14.
} 
cobrados são mais favoráveis do que os direitos consolidados, por causa do denominado princípio da consolidaçãa ${ }^{48}$. Agora, como já vimos, o Memorando diz claramente que "os direitos aduaneiros e as imposiçōes a ter em conta serão as taxas dos direitos aplicados".

Já em relação à expressão "outras regulamentações comerciais", o Ciclo do Uruguai não trouxe nenhuma novidade importante, o que não deixa de ser criticável, se tivermos em consideração que, nos dias de hoje, os obstáculos mais importantes ao comércio internacional são os de natureza não-pautal ${ }^{49}$.

Depois da entrada em funçôes da OMC, o único aspecto a realçar prende-se com a seguinte conclusão de um Painel:

"ainda que os membros não tenham chegado a acordo sobre uma definição que determine o alcance do conceito de 'outras regulamentaçôes comerciais', para os

\footnotetext{
${ }^{48}$ Ao mesmo tempo que se reduzem os direitos aduaneiros, convém evitar que, no futuro, eles sofram aumentos. Recorre-se, então, à técnica ou princípio da consolidação, prevista no n. ${ }^{\circ} 1$ do art. II do GATT, através da qual os Membros da OMC se obrigam, a partir de uma determinada data, a conceder ao comércio dos outros Membros um tratamento não menos favorável que o previsto nas correspondentes listas de concessões. Por conseguinte, os Membros comprometem-se a não aplicar direitos aduaneiros mais elevados do que os consolidados nas respectivas listas de concessões, anexadas ao GATT e com o mesmo valor deste (art. II, n. os 1, alínea $b$ ), e 7, do GATT), nem a modificar o respectivo método de determinação do valor aduaneiro ou o seu método de conversão das moedas, de uma maneira tal que o valor das concessões incluídas na correspondente lista venha a ficar reduzido (art. II, n. ${ }^{0} 3$, do GATT). A consolidação de um direito aduaneiro num determinado limite não significa, contudo, que esse seja o direito efetivamente cobrado. Na prática, o direito cobrado pode ser inferior ou igual ao valor consolidado, não pode é ser superior a esse valor. Por exemplo, apesar de o Chile aplicar no início deste século um direito aduaneiro de $9 \%$ a todas as importações, todos os seus direitos aduaneiros estavam consolidados em 35\% (cf. Pierre Sauvé e Arvind Subramanian, Dark Clouds over Geneva? The Troubled Prospects of the Multilateral Trading System, in Efficiency, Equity, and Legitimacy: The Multilateral Trading System at the Millennium, Roger Porter, Pierre Sauvé, Arvind Subramanian e Americo Zampetti ed., Brookings Institution Press, Washington, D.C., 2001, p. 21). Em relação aos produtos não constantes das listas de concessões, os membros da OMC mantêm a liberdade de cobrar o direito aduaneiro que bem entenderem, inclusive direitos aduaneiros proibitivos (os direitos aduaneiros de montante suficientemente elevado para impedirem todas as importações de um determinado bem). Esta faculdade dos Membros da OMC encontra-se, no entanto, cada vez mais cerceada, visto que o Ciclo do Uruguai conseguiu aumentos sensíveis quanto à percentagem de trocas comerciais sujeitas ao princípio da consolidação: 99\% para os países desenvolvidos, 73\% para os países em desenvolvimento e 98\% para os países em transição para uma economia de mercado. Estes valores traduzem-se, como é evidente, numa maior segurança dos agentes econômicos na condução das suas atividades comerciais.

${ }^{49} 0$ Memorando de Entendimento sobre a Interpretação do Artigo XXIV do GATT de 1994 limita-se a reconhecer que, "para efeitos da avaliação global da incidência de outras regulamentações comerciais de difícil quantificação e agregação, poderá ser necessário examinar cada medida, regulamentação e produto abrangido, bem como 0 fluxo comercial afectado" (parágrafo 2. ${ }^{\circ}$ in fine).
} 
nossos propósitos, é claro que este conceito engloba as restrições quantitativas. De uma maneira mais geral, o sentido corrente dos termos 'outras regulamentações comerciais' poderia ser entendido como incluindo toda a regulamentação que tenha uma incidência sobre o comércio (por exemplo, as medidas tomadas nos domínios abrangidos pelas regras da OMC, tais como as medidas sanitárias e fitossanitárias, o valor aduaneiro, as medidas antidumping, os obstáculos técnicos ao comércio; assim como todas as outras regulamentações internas ligadas ao comércio, tais como as normas ambientais e os sistemas de crédito à exportação). Dada a natureza dinâmica dos acordos comerciais regionais, consideramos que estamos perante um conceito evolutivo [an evolving concept]"

Convém ter presente ainda a respeito do critério relativo ao comércio externo que, regra geral, a criação de uma pauta aduaneira comum implica para os membros da união aduaneira reduções ou aumentos dos direitos aduaneiros ${ }^{51} \mathrm{e}$, como foi já referido, a elevação de um direito aduaneiro anteriormente consolidado é contrária às regras do GATT (art. II). O no 6 do art. XXIV determina, por isso, que:

"se, ao cumprir as condições enunciadas na alínea a) do no 5 , um membro se propôe elevar um direito de uma forma incompatível com as disposiçôes do artigo II, será aplicável o processo previsto no artigo XXVIII".

O Memorando de Interpretação do Artigo XXIV determina, por outro lado, que o procedimento previsto no art. XXVIII do GATT deve ser iniciado:

"antes da alteração ou retirada das concessóes pautais quando da criação de uma união aduaneira ou da conclusão de um acordo provisório tendo em vista o estabelecimento de uma união aduaneira" (parágrafo 4\%).

Ao mesmo tempo, a parte final do no 6 do art. XXIV estabelece que, se um Membro da OMC tiver de aumentar, quando da fixação dos direitos da pauta aduaneira comum, os seus direitos aduaneiros sobre um determinado produto, deve-se tomar em consideração o fato de os direitos aduaneiros aplicados sobre o mesmo produto pelos outros membros da união poderem ter sofrido uma redução. Segundo Youri Devuyst:

\footnotetext{
${ }^{50}$ Relatório do Painel no caso Turkey - Restrictions on Imports of Textile and Clothing Products, 31-5-1999, parágrafo 9.120. De notar que, enquanto no n. ${ }^{\circ} 5$ e no n. ${ }^{\circ} 8$, alínea $a$ ) (ii), do art. XXIV do GATT aparece o termo "outras regulamentações comerciais", nas alíneas $a$ ) (i) e $b$ ) do n. ${ }^{\circ} 8$ do mesmo artigo surge o termo "outras regulamentações comerciais restritivas". Será que os dois termos são sinônimos?

${ }^{51}$ Só não será assim se os membros da União, quando do estabelecimento da pauta aduaneira, utilizaram 0 método de alinhamento pelo direito mais baixo aplicado entre eles.
} 
"these tariff decreases on the same tariff-line are called internal credits and are relatively uncontested"

Caso as reduções ligadas ao estabelecimento da pauta aduaneira comum não sejam suficientes para proporcionar a necessária compensação, a união aduaneira poderá oferecer uma compensação assumindo a forma de reduções de direitos aduaneiros em outras linhas pautais. Tal oferta será tomada em consideração pelos membros da OMC com direitos de negociação na consolidação alterada ou retirada. Caso a compensação permaneça inaceitável, as negociações deverão prosseguir. Quando, apesar desses esforços, for impossível chegar a acordo no âmbito das negociações sobre a compensação prevista no art. XXVIII do GATT, a união aduaneira poderá, no entanto, alterar ou retirar as concessões. Os membros da OMC afetados têm, então, a faculdade de retirar concessóes substancialmente equivalentes, em conformidade com o disposto no art. XXVIII.

Quanto à chamada reverse compensation (suscitada, por exemplo, quando da adesão da Grécia à Comunidade Econômica Européia, visto a incidência geral dos direitos aduaneiros do novo membro da Comunidade ter diminuído substancialmente em comparação com o nível dos direitos cobrados antes da adesão), será que é de esperar, em tal situação, que um Membro da OMC (no exemplo referido, a Comunidade Econômica Européia) receba uma compensação dos outros membros da OMC que beneficiaram da redução ocorrida? De acordo com o parágrafo $6^{\circ}$, in fine, do Memorando de Entendimento sobre a Interpretação do Artigo XXIV:

"O GATT de 1994 não impōe aos Membros que beneficiem de uma redução dos direitos aduaneiros na seqüência do estabelecimento de uma união aduaneira, ou da conclusão de um acordo provisório tendo em vista o estabelecimento de uma união aduaneira, qualquer obrigação de concessão de um ajustamento de compensação às suas entidades constitutivas" (itálico aditado).

Finalmente, o no 8, alínea a)(ii), do art. XXIV do GATT exige, somente em relação às uniōes aduaneiras, que:

"os direitos aduaneiros e outras regulamentaçôes comerciais aplicados por cada um dos membros da união ao comércio com os territórios que não estão nesta compreendidos sejam substancialmente idênticos".

\footnotetext{
${ }^{52}$ Youri Devuyst, GATT Customs Union Provisions and the Uruguay Round: The European Community Experience, in Journal of World Trade, 1992, p. 23.

${ }^{53}$ Relatório do Órgão de Recurso no caso Turkey - Restrictions on Imports of Textile and Clothing Products, 22-10-1999, parágrafo 49.
} 
Deste modo, os membros de uma união aduaneira são obrigados a aplicar um regime comum para o comércio externo, tanto no que respeita aos direitos aduaneiros como a outras regulamentações comerciais. No entanto, segundo o Órgão de Recurso:

"o no 8 , alínea $a$ )(ii) não exige que cada membro constitutivo de uma união aduaneira aplique direitos aduaneiros e outras regulamentaçôes comerciais identicos às dos outros membros constitutivos quanto ao comércio com países terceiros; de fato, ele exige que sejam aplicados direitos aduaneiros e outras regulamentaçōes comerciais substancialmente idênticos. Concordamos com o entendimento do Painel segundo o qual 'o sentido comum do termo 'substancialmente' no contexto do no 8 , alínea $a$ ) comporta simultaneamente elementos qualitativos e quantitativos. A frase 'os direitos aduaneiros e outras regulamentaçôes comerciais aplicados por cada um dos membros da união [aduaneira] ao comércio (...) sejam substancialmente idênticos' parece comportar simultaneamente elementos quantitativos e qualitativos, tendo o aspecto quantitativo maior relevo no que toca aos direitos aduaneiros" ${ }^{, 53}$.

Ainda segundo o Órgão de Recurso,

“entendemos que o Painel tinha razão ao afirmar que o no 8 , alínea a)(ii) e, em especial, a frase 'substancialmente idênticos', oferecem alguma flexibilidade aos membros constitutivos de uma união aduaneira na 'elaboração de uma política comercial comum'. Também aqui relembramos que essa 'flexibilidade’ é limitada. É preciso não esquecer que o termo 'substancialmente' qualifica o termo 'idênticos'. Por conseguinte, em nosso entender, o art. XXIV, no 8 , alínea $a$ )(ii), exige que exista algo muito próximo da 'identidade'. Não acolhemos a opinião do Painel segundo a qual

'(...) em regra geral, uma situação na qual os membros constitutivos adoptaram regulamentação comerciais 'comparáveis' que produzem efeitos semelhantes quanto ao comércio com países terceiros seria no seu conjunto conforme com o aspecto qualitativo das prescrições enunciadas no $\mathrm{n}^{\circ} 8$, alínea $a$ ) (ii)'.

$\mathrm{O}^{\circ} 8$, alínea $a$ )(ii) dispõe que os membros constitutivos de uma união aduaneira devem adoptar regulamentações comerciais 'substancialmente idênticas'. Em nosso entender, as 'regulamentaçôes comparáveis que produzem efeitos semelhantes' não satisfazem esse critério. $\mathrm{O} \mathrm{n}^{\circ} 8$, alínea $a$ )(ii) exige um grau mais elevado de identidade" ${ }^{\prime 54}$.

${ }_{54}^{5 e l a t o ́ r i o ~ d o ~ O ́ r g a ̃ o ~ d e ~ R e c u r s o ~ n o ~ c a s o ~ T u r k e y ~-~ R e s t r i c t i o n s ~ o n ~ I m p o r t s ~ o f ~ T e x t i l e ~ a n d ~ C l o t b i n g ~ P r o d u c t s, ~}$ 22-10-1999, parágrafo 50. 


\section{c) Os Critérios Formais}

Para além dos dois critérios de fundo já referidos, o art. XXIV do GATT impõe também algumas formalidades à criação de zonas de comércio livre e de uniões aduaneiras. Assim, admitindo o art. XXIV a possibilidade de um período transitório necessário ao estabelecimento de uma união aduaneira ou de uma zona de comércio livre, a alínea $c$ ) do seu n 5 estabelece que o acordo provisório tendente à adoção daquelas formas de integração econômica deverá compreender "um plano e um programa para o estabelecimento, num prazo razoável, da união aduaneira ou da zona de comércio livre”.

No sentido de disciplinar a instituição de acordos provisórios (por exemplo, o acordo de associação celebrado nos anos sessenta entre a Grécia e a Comunidade Econômica Européia previa um período transitório de 22 anos para cerca de $30 \%$ das importaçōes gregas da Comunidade Econômica Européia), o Memorando de Entendimento sobre a Interpretação do Artigo XXIV do GATT de 1994 determina que o prazo razoável não deve ultrapassar, salvo em casos excepcionais, dez anos (parágrafo $3^{\circ}$ ). Caso os membros que são parte num acordo provisório considerem insuficiente um prazo de dez anos, deverão explicar pormenorizadamente ao Conselho do Comércio de Mercadorias a razão pela qual é necessário um prazo mais longo. Por exemplo, o período transitório de 12 anos previsto na Convenção de Cotonou para a celebração de acordos de comércio livre entre os países ACP (África, Caraíbas e Pacífico) e a Comunidade Européia não é, em nossa opinião, contrário às regras da $\mathrm{OMC}$, dadas as diferenças de desenvolvimento econômico entre os países envolvidos.

Curiosamente, o GATT nada diz sobre se o plano e o programa devem ser detalhados ou não.

Por fim, merece atenção o fato de o critério "do essencial das trocas comerciais" se aplicar aos países membros dos blocos econômicos regionais, mas não às partes de qualquer acordo provisório concluído com vista ao estabelecimento de uma união aduaneira ou de uma zona de comércio livre. Em contrapartida, o critério relativo ao comércio externo aplica-se quer às zonas de comércio livre e uniōes aduaneiras, quer aos acordos provisórios concluídos com vista ao seu estabelecimento.

A outra formalidade encontra-se prevista no no 7 , alínea $a$ ), do art. XXIV, nos termos do qual:

"qualquer membro da Organização Mundial do Comércio que decida entrar numa união aduaneira ou numa zona de comércio livre, ou participar num acordo provisório concluído com vista ao estabelecimento de uma tal união ou de uma tal zona, deve notificar, sem demora, os outros membros e fornecer-lhes, no que respeita à união ou zona em projecto, todas as informaçōes". 
Se estes, depois de terem estudado o plano e o programa compreendidos num acordo provisório, chegarem à conclusão de que o acordo não oferece possibilidades de conduzir ao estabelecimento de uma união aduaneira ou de uma zona de comércio livre nos prazos previstos pelas partes do acordo, ou de que estes prazos não são razoáveis, dirigirão recomendaçôes às partes do acordo. Depois, as partes do acordo gozam de três possibilidades:

- a modificação do acordo, em conformidade com as recomendaçōes feitas pelos outros membros da OMC (art. XXIV, no 7, alínea b) $)^{55}$;

- a obtenção de uma derrogação, hipótese prevista quer no art. XXIV, nº 10, do GATT de 1994, quer no art. IX, nos 3 e 4, do Acordo $\mathrm{OMC}^{56}$; e

- o exercício do direito de recesso (art. XV do Acordo OMC).

A realidade mostra, apesar de tudo, que os textos dos tratados institutivos de muitos blocos econômicos regionais são notificados, muitas vezes, quando as negociações relativas aos mesmos já terminaram ou quando já entraram em vigor, o que, como é óbvio, põe em causa a eficácia do processo de exame $e^{57}$. Aliás, alguns dos blocos econômicos regionais atualmente em vigor não foram sequer notificados à $\mathrm{OMC}$, em particular os acordos preferenciais entre países em desenvolvimento ${ }^{58}$.

Seja como for, o fato de o Comité dos Acordos Comerciais Regionais se deparar normalmente com fatos consumados não é, em boa verdade, uma questão tão relevante quanto se poderia julgar. Basta ver que o Comité dos Acordos Comerciais Regionais toma as decisões por consenso, o que significa que os membros da OMC que fazem parte do

\footnotetext{
${ }^{55}$ Qualquer modificação substancial no plano ou no programa referidos na alíneac) do n. ${ }^{\circ}$ do art. XXIV do GATT deverá ser comunicada aos membros, que poderão pedir às partes do acordo em causa para entrarem em consultas com elas, se a modificação parece vir a comprometer ou a atrasar indevidamente o estabelecimento da união aduaneira ou da zona de comércio livre (art. XXIV, n. ${ }^{0} 7$, alínea c), do GATT).

${ }^{56}$ Apesar de os trabalhos preparatórios revelarem que o n. ${ }^{0} 10$ do art. XXIV do GATT visava, essencialmente, as zonas de comércio livre e as uniões aduaneiras com países que não eram partes contratantes do GATT (cf. OMC, Le regionalisme et le système commercial mondial, p. 13), atualmente, entende-se que esta disposição permite aos membros da Organização Mundial do Comércio aprovar, por decisão tomada por maioria de dois terços, propostas que não estejam inteiramente de harmonia com os seus n . $^{\circ} 5$ a 9 , com a condição de que tais propostas conduzam ao estabelecimento de uma união aduaneira ou de uma zona de comércio livre.

${ }^{57}$ Por exemplo, embora o NAFTA tenha sido assinado no dia 17 de Dezembro de 1992 e entrado em vigor no dia 1 de Janeiro de 1994, o grupo de trabalho responsável pelo exame da sua compatibilidade com o GATT só foi criado em 23 de Março de 1994.

${ }^{58}$ OMC, Compendium of Issues Related to Regional Trade Agreements, Background Note by the Secretariat, 1-8-2002, p. 5.
} 
bloco econômico regional e que participam nos trabalhos daquele comité não vão votar a favor da incompatibilidade do bloco em causa com as regras do GATT ${ }^{59}$. E, de fato, de acordo com o relatório de 2003 da OMC, "no examination report has been finalized since 1995 because of lack of consensus"

É verdade que existe ainda a possibilidade de a questão da compatibilidade de um bloco econômico regional com as regras do GATT ser analisada por um Painel ou pelo Órgão de Recurso (parágrafo $12^{\circ}$ do Memorando de Entendimento sobre a Interpretação do Artigo XXIV do GATT de $1994^{61}$ ), mas, também aqui, é necessário ter em conta que as medidas correctivas no âmbito da OMC não se aplicam retroactivamente, apenas ex nunc.

\section{d) A Relevância dos Critérios no GATT de 1947}

Dos noventa e oito acordos regionais notificados no período de 1948-1994, nenhum foi declarado incompatível, embora apenas seis, todos de importância reduzida, tenham sido formalmente declarados compatíveis com o art. XXIV, $n^{\circ}{ }_{S} 4$ a $10^{62}$, a saber: I) o acordo provisório com vista à criação de uma união aduaneira entre a África do Sul e o Zimbabué;

II) a zona de comércio livre entre El Salvador e a Nicarágua;

III) a participação da Nicarágua no estabelecimento de uma zona de comércio livre na América Central (no momento da conclusão do tratado, a Nicarágua era o único membro da zona de comércio livre da América Central, constituída pela Costa Rica, El Salvador, Guatemala, Honduras e Nicarágua, que era parte contratante do GATT);

IV) o Acordo de Comércio Livre das Caraíbas, que criou uma zona de comércio livre entre Antígua, Barbados, Guiana e Trindade e Tobago (posteriormente substituída pelo Tratado Institutivo da Comunidade das Caraíbas);

\footnotetext{
${ }^{59}$ Em 6 de Fevereiro de 1996, o Conselho Geral criou o Comité dos Acordos Comerciais Regionais. O Comitédos Acordos Comerciais Regionais, que ocupou o lugar dos diferentes grupos de trabalho ad hoc anteriormente estabelecidos para o exame de tais acordos, tem por funções examinar os acordos regionais notificados, formular recomendações, desenvolver procedimentos que facilitem e melhorem o processo de exame e considerar as implicações dos acordos para o sistema comercial multilateral. Cf. OMC, Committee on Regional Trade Agreements, 7-2-1996. ${ }^{60}$ OMC, Annual Report 2003, ed. OMC, 2003, p. 29.

${ }^{61}$ De acordo com este parágrafo 12. ', "as disposições dos artigos XXII e XXIII do GATT de 1994, tal como definidas e aplicadas pelo Memorando de Entendimento sobre Resolução de Litígios, poderão ser invocadas no que diz respeito a qualquer questão decorrente da aplicação das disposições do artigo XXIV relativas às uniões aduaneiras, às zonas de comércio livre ou aos acordos provisórios concluídos tendo em vista o estabelecimento de uma união aduaneira ou de uma zona de comércio livre".

${ }^{62}$ OMC, Le regionalisme et le système commercial mondial, 1995, p. 20.
} 
V) a Comunidade e Mercado Comum das Caraíbas, mais conhecida por CARICOM (acordo provisório com vista à criação de uma união aduaneira entre os Barbados, a Guiana, a Jamaica e Trindade e Tobago); e

VI) o acordo estabelecendo uma união aduaneira entre a República Checa e a República Eslovaca.

Destes seis acordos, apenas dois se mantêm em vigor: o CARICOM e a união aduaneira entre a República Checa e a República Eslovaca.

Para a escassez de acordos formalmente declarados compatíveis com o art. XXIV do GATT, podem ter contribuído os seguintes fatores:

I) os grupos de trabalho do GATT tomavam as decisões por consenso;

II) os membros do bloco econômico regional em exame eram igualmente membros do grupo de trabalho;

III) o bloco econômico regional, negociado laboriosamente entre os seus membros e aprovado pelos respectivos parlamentos nacionais, quando do exame do grupo de trabalho, estava já muitas vezes em funcionamento;

IV) alguns dos requisitos estabelecidos pelo art. XXIV do GATT não se encontravam definidos de um modo preciso; e

V) a presença de objetivos políticos importantes na maioria dos blocos econômicos regionais ${ }^{63}$.

Apesar de tudo, as condições impostas pelo art. XXIV do GATT parecem ter desempenhado um papel importante. Por um lado:

"the scrutiny of the process has helped bring indirect pressure on Regional Trade Agreements members not to go too far in abusing Article XXIV rules and has brought sharp focus on the problem issues ${ }^{, 64}$.

Por exemplo, os critérios do art. XXIV foram fatores que influenciaram a redação do Tratado institutivo da Associação Latino-Americana de Integração ${ }^{65}$, o mesmo acontecendo com os acordos celebrados pelos EUA com o Canadá e Israel ${ }^{66}$.

\footnotetext{
${ }^{63}$ Richard Blackhurst e David Henderson, Regional Integration Agreements, World Integration and the GATT, in Regional Integration and the Global Trading System, Kym Anderson e Richard Blackhurst ed., Harvester Wheatsheaf, 1993, p. 427.

${ }_{64}^{64}$ Robert E. Hudec e James D. Southwick, Regionalism and WTO Rules ..., p. 52.

${ }^{65}$ Kenneth W. Dam, The GATT Law and International Economic Organization, The University of Chicago Press, Chicago e Londres, 1970, p. 291.

${ }^{66}$ Banco Mundial, Trade Blocs, p. 121.
} 
Por outro lado, não sabemos que potenciais blocos regionais foram desencorajados simplesmente por causa da sua existência no texto do GATT ${ }^{67}$.

Na prática, apesar do grande número de acordos notificados ao abrigo do art. XXIV, da ausência de consenso sobre a compatibilidade da grande maioria desses acordos com o GATT e da terminologia algo nebulosa utilizada por aquela disposição, somente três dos blocos regionais notificados, e respectivo tratamento preferencial, deram azo a que se recorresse ao processo de resolução de litígios previsto nos arts. XXII e XXIII do GATT. Talvez porque, como observam JAIME SERRA et al.:

"since every WTO member is part of a formal or informal regional arrangement, there seems to be a silent acceptance of Article XXIV's problems" ${ }^{68}$.

Nos três casos, a parte incriminada foi sempre a Comunidade Européia e em nenhum caso foi o relatório do Painel adotado pelo Conselho dos Representantes.

\subsection{Os Blocos Econômicos Regionais entre Países em Desenvolvimento}

Apesar de ser a disposição mais conhecida, o art. XXIV do GATT não constitui a única disposição do sistema GATT/OMC a lidar com os blocos econômicos regionais. Por exemplo, antes da entrada em vigor dos acordos do Ciclo do Uruguai, a chamada Parte IV do GATT foi invocada, várias vezes, em relação aos acordos comerciais preferenciais que não satisfaziam o critério relativo ao "essencial das trocas comerciais" (o caso das Convençōes de Lomé I, II e III celebradas entre a Comunidade Econômica Européia e os Países ACP) e, em virtude do no 2 , alínea $c$ ), da chamada Cláusula de Habilitação ${ }^{69}$, que constitui uma exceção aos arts. I, $\mathrm{n}^{\circ} 1$, eXXIV, $\mathrm{n}^{\mathrm{o}} \mathrm{s} 4$ a 10, do GATT $^{70}$, o tratamento diferenciado e preferencial passou a aplicar-se aos acordos regionais ou mundiais concluídos entre países em desenvolvimento com vista à redução ou eliminação de direitos aduaneiros e de obstáculos não pautais numa base mútua.

\footnotetext{
${ }^{67}$ Banco Mundial, Trade Blocs, 2001, in www.worldbank.org/trade, p. 110.

${ }^{68}$ Jaime Serra et al., Reflections on Regionalism: Report of the study group on international trade, Carnegie endowment for international peace, Washington, D.C., 1997, p. 32.

${ }^{69}$ Apesar de vulgarmente conhecida por Cláusula de Habilitação, o seu nome completo é "Tratamento Diferenciado e Mais Favorável, Reciprocidade e Participação Mais Completa dos Países em Desenvolvimento". A sua adoção aconteceu no Ciclo de Tóquio e o seu texto pode ser encontrado in Luís Máximo dos Santos, Luís Morais e Fernando Pereira Ricardo, Textos de Relações Econômicas Internacionais, 2. ${ }^{a}$ ed., Associação Académica da Faculdade de Direito de Lisboa, 1999/2000, pp. 277-282.

${ }^{70}$ Jürgen Huber, The practice of GATT in examining regional arrangements under article XXIV, In: Journal of Common Market Studies, 1981, p. 297.
} 
No caso da Cláusula de Habilitação, as condições a observar pelos acordos, menos rigorosas que as estabelecidas no art. XXIV do GATT, são as seguintes:

I) devem ser concebidos para facilitar e promover o comércio dos países em desenvolvimento e não para aumentar os obstáculos ou criar dificuldades indevidas ao comércio de quaisquer outros membros (nº 3, alínea a), da Cláusula de Habilitação);

II) não devem constituir um entrave à redução ou à eliminação de direitos aduaneiros ou de outras restrições ao comércio na base do tratamento da nação mais favorecida ( $n^{\circ} 3$, alínea b), da Cláusula de Habilitação);

III) os acordos devem ser notificados aos membros da OMC quando são instituídos, modificados ou denunciados, devendo as partes dos acordos fornecer-lhes todas as informaçôes por aqueles consideradas apropriadas e realizarem consultas, quando para tal forem solicitadas por qualquer membro da OMC interessado ( $\mathrm{n}^{\circ} 4$ da Cláusula de Habilitação). A notificação do acordo do MERCOSUL, por exemplo, foi feita ao abrigo da Cláusula de Habilitação.

Dito isto, convém notar que o tratamento diferenciado e preferencial previsto na Cláusula de Habilitação se aplica somente aos acordos regionais ou mundiais concluídos entre países em desenvolvimento que sejam membros da OMC; de fora do âmbito da cláusula, ficam, portanto, os blocos econômicos regionais concluídos entre países desenvolvidos e países em desenvolvimento ou entre países em desenvolvimento em que um deles não é membro da OMC.

\subsection{O Artigo V do GATS}

Reconhecendo que os blocos econômicos regionais aumentaram muito em número e importância desde a entrada em vigor do GATT de 1947, representando atualmente uma parte significativa do comércio mundial, alguns dos novos acordos comerciais multilaterais saídos do Ciclo do Uruguai contêm disposiçôes aplicáveis àqueles blocos. A mais importante dessas novas disposiçôes é claramente o art. V do Acordo Geral sobre o Comércio de Serviços (GATS), o qual impõe que um acordo de liberalização do comércio de serviços entre membros da OMC observe as seguintes condições:

(I) tenha uma cobertura setorial significativa, em termos de número de setores, volume de comércio afetado e modos de prestação (art. V, no 1, alínea a));

(II) preveja a ausência ou a eliminação em termos substanciais de todo o tipo de discriminação entre as partes nos setores abrangidos pela alínea $a$ ), através da eliminação de medidas de carácter discriminatório existentes e/ou da proibição da introdução de 
novas medidas de carácter discriminatório ou de medidas mais discriminatórias (art. V, no 1 , alínea $b)$ );

(III) deve destinar-se a promover o comércio entre as partes no acordo e não aumentar relativamente a qualquer membro que não participe no acordo, o nível global de obstáculos ao comércio de serviços nos respectivos setores ou subsetores, comparativamente com o nível aplicável antes da conclusão desse acordo (art. V, no 4); e

(IV) os membros que sejam parte ou subscrevam um acordo de liberalização do comércio de serviços devem notificar prontamente o Conselho do Comércio de Serviços de qualquer acordo desse tipo e facultar-lhe todas as informaçoes relevantes (art. V, no 7, alínea $a$ )).

É de notar, ainda, que, embora a criação de um grupo de trabalho responsável por examinar cada acordo não seja obrigatória ( $\operatorname{art.~} \mathrm{V}, \mathrm{n}^{\circ} \mathrm{7}$, alínea $a$ )), não existe no GATS uma proibição específica, como sucede no GATT, quanto à manutenção de um acordo se as recomendações feitas pelo Conselho do Comércio de Serviços não forem seguidas. Além disso, o GATS não faz qualquer distinção entre zona de comércio livre e união aduaneira, falando apenas em integração econômica. Por último, é de salientar que, como foi já referido, o art. V do Acordo Geral sobre o Comércio de Serviços impõe que um acordo de liberalização do comércio de serviços entre membros da OMC tenha uma cobertura setorial significativa, em termos de número de setores, volume de comércio afetado e modos de prestação. Para satisfazer esta condição, os acordos não devem prever a exclusão a priori de qualquer modo de prestação (art. V, no 1 , alínea $a$ )). $\mathrm{O}$ art. V do GATS é, pois, bem mais concreto que o art. XXIV do GATT, visto tornar claro que nem todos os setores precisam de ser incluídos. Além disso, em vez de estabelecer que os direitos aduaneiros e outras regulamentações comerciais não devem ser mais elevados ou restritivos, o GATS requer, sim, a ausência ou a eliminação em termos substanciais de todo o tipo de discriminação entre as partes nos setores abrangidos pela alínea $a$ ), através da eliminação de medidas de carácter discriminatório existentes e/ou da proibição da introdução de novas medidas de carácter discriminatório ou de medidas mais discriminatórias (art. V, no 1, alínea b), do GATS). Enfim, o GATS autoriza expressamente a manutenção de medidas contrárias ao disposto no seu art. $V$ por razões de segurança (art. V, no 1 , alínea $b$ )(ii), in fine).

Ao invés, o art. $V$ do GATS é pouco claro quanto ao significado do requisito "não aumentar relativamente a qualquer membro que não participe no acordo, o nível global de obstáculos ao comércio de serviços nos respectivos setores ou subsetores, comparativamente com o nível aplicável antes da conclusão desse acordo", previsto no art. V, nº 4. Na prática, como é que tal requisito deverá ser interpretado? Para mais, as barreiras ao comércio de 
serviços assumem, na maior parte dos casos, a forma de leis, decretos e práticas reguladoras, o que torna virtualmente impossível atribuir-lhes um valor quantitativo ${ }^{71}$.

\section{O Caso Turkey - Restrictions on Imports of Textile and Clothing Products}

No contexto do Acordo de Associação entre a Turquia e a Comunidade Européia (cuja origem remonta ao ano de 1963), o Conselho de Associação Comunidade Européia - Turquia adotou no dia 6 de Março de 1995 a decisão no 1/95, que estabelece as regras relativas à execução da fase final da união aduaneira entre a Turquia e a Comunidade Européia. Segundo o no 2 do art. $12^{\circ}$ da Decisão,

"em conformidade com as prescrições do artigo XXIV do GATT, a Turquia aplicará, a partir da data de entrada em vigor da presente decisão, uma política comercial substancialmente equivalente à da Comunidade para o setor têxtil, incluindo os acordos ou arranjos relativos ao comércio de produtos têxteis e de vestuário".

Com vista à aplicação do que a Turquia considerou ser "uma política comercial substancialmente idêntica” à da Comunidade Européia e, por isso, abrangida pelo art. XXIV do GATT, a Turquia introduziu, em Janeiro de 1996, restrições quantitativas à importação de 19 categorias de produtos têxteis e de vestuário originários da Índia.

Depois de o Painel ter concluído que as restrições quantitativas aplicadas pela Turquia violavam os arts. XI e XIII do GATT de 1994 e o no 4 do art. 2º do Acordo sobre os Têxteis e o Vestuário, o Órgão de Recurso entendeu, com base numa análise do texto e contexto do prólogo do no 5 do artigo XXIV do GATT, que a criação de um bloco econômico regional pode justificar a adoção de medidas que sejam contrárias às regras do GATT, mas apenas se três condiçōes forem respeitadas pelo membro que recorra ao art. XXIV:

I) a violação das regras da OMC não pode ocorrer depois de criado o bloco econômico regional;

II) o membro da OMC que invoque as regras relativas aos blocos econômicos regionais para justificar as medidas que adotou deve provar que o bloco que pretende estabelecer é claramente compatível com os no 5 e 8 do art. XXIV do GATT; e

\footnotetext{
${ }^{71}$ Sherry Stephenson, GATS and Regional Integration, in GATS 2000: New Directions in Services Trade Liberalization, Pierre Sauvé e Robert Stern ed., Brookings Institution Press, Washington, D.C., 2000, p. 519.
} 
III) é necessário demonstrar que a criação de uma união aduaneira (ou de uma zona de comércio livre) não é possível sem a introdução da medida que é considerada contrária às regras do GATT $^{72}$.

No que diz respeito a esta última condição, o Órgão de Recurso assinalou que:

"concordamos com o Painel que, se a Turquia não tivesse adotado restrições quantitativas idênticas às aplicadas pelas Comunidades Européias, tal não teria impedido a Turquia e as Comunidades Européia de satisfazerem as exigências do artigo XXIV, no 8, alínea a)(I) e, consequentemente, de estabelecerem uma união aduaneira. Relembramos a nossa conclusão segundo a qual os termos do ${ }^{\circ}$ 8, alínea $a$ )(I) permitem alguma flexibilidade - ainda que limitada - aos membros constitutivos de uma união aduaneira na liberalização do respectivo comércio interno. Como o Painel observou, a Turquia e as Comunidades Européias dispõem de outras soluções possíveis para impedir um eventual desvio de comércio e, ao mesmo tempo, respeitar as condiçōes do no 8 , alínea $a$ )(I). Por exemplo, a Turquia poderia adoptar regras de origem para os produtos têxteis e de vestuário que permitiriam às Comunidades Européias fazer a distinção entre os produtos originários da Turquia, os quais beneficiariam de livre acesso ao mercado comunitário através da união aduaneira, $e$ os produtos têxteis e de vestuário originários de países terceiros, incluindo a Índia, ${ }^{73}$.

Em suma, o entendimento do Órgão de Recurso "almost introduces a reverse consensus rule suggesting that, unless otherwise proven, any Regional Trade Agreements and Regional Trade Agreement preferences are contrary to the WTO multilateral rules" ${ }^{\text {"74 }}$. Sungjoon Cho vai mesmo mais longe, considerando que:

"the Appellate Body de fato invented a new test, analogous to the Article XX, paragraph $b$, 'least trade-restrictive' approach, to regulation of the trade-diverting effect of Regional Trade Agreements, for specific application to Article XXIV"75.

\footnotetext{
${ }^{72}$ Relatório do Órgão de Recurso no caso Turkey - Restrictions on Imports of Textile and Clothing Products, 22-10-1999, parágrafos 52, 58 e 62-63.

${ }^{73}$ Relatório do Órgão de Recurso no caso Turkey - Restrictions on Imports of Textile and Clothing Products, 22-10-1999, parágrafo 62.

${ }^{74}$ Gabrielle Marceau e Cornelis Reiman, When and How Is a Regional Trade Agreement Compatible with the WTO?, in Legal Issues of Economic Integration, 2001, p. 297.

${ }^{75}$ Sungjoon Cho, Breaking the Barrier Between Regionalism and Multilateralism ..., p. 448.
} 
Contudo, limitando-se o prólogo do no 5 do art. XXIV a dizer que "as disposições deste Acordo não constituirão obstáculo ao estabelecimento (...) de uma união aduaneira ou de uma zona de comércio livre ...”, é forçoso concluir que a condição de que a violação das regras da OMC não pode ocorrer depois de criado o bloco econômico regional não encontra qualquer apoio no texto do prólogo, o mesmo sucedendo com a condição de que é necessário demonstrar que a criação de uma união aduaneira ou de uma zona de comércio livre não é possível sem a introdução da medida que é considerada contrária às regras do GATT. Se virmos bem, o prólogo do no 5 do art. XXIV nada diz sobre o momento em que as medidas têm de ser introduzidas para poderem ser justificadas ao abrigo do art. XXIV e a palavra "necessário" só aparece a respeito dos acordos provisórios, não a propósito da relação entre determinadas medidas ou violaçôes do GATT e a formação de um bloco econômico regional compatível com o GATT ${ }^{76}$. Ora, tendo o Órgão de Recurso considerado que a regra geral de interpretação consagrada no no 1 do art. $31^{\circ}$ da Convenção de Viena sobre o Direito dos Tratados, de 23 de Maio de 1969, "se transformou numa regra de direito internacional consuetudinário ou geral" 77 , regra que os painéis e o Órgão de Recurso devem observar quando procuram clarificar as disposições dos acordos da OMC (art. 3 ${ }^{\circ}$, no 2, do Memorando de Entendimento sobre as Regras e Processos que Regem a Resolução de Litígios), não deixa de ser estranho que o Órgão de Recurso tenha chegado às conclusões supracitadas.

Muito importante é a conclusão do Órgão de Recurso, segundo a qual o art. XXIV pode, se observadas certas condições, justificar a adoção de uma medida que é incompatível com certas outras disposiçōes do GATT e não apenas com a cláusula da nação mais favorecida do $\mathrm{n}^{\mathrm{o}} 1$ do art. I, e que ele pode ser invocado como uma possível 'defesa' contra uma conclusão de incompatibilidade ${ }^{78}$.

\footnotetext{
${ }_{77}^{76}$ Joost Pauwelyn, The Puzzle of WTO Safeguards ..., pp. 132-133.

Relatório do Órgão de Recurso no caso United States - Standards for Reformulated and Conventional Gasoline, 29-4-1996, p. 17. De acordo com o n. ${ }^{\circ} 1$ do art. 31. ${ }^{\circ}$ da Convenção de Viena, "um Tratado deve ser interpretado de boa fé, segundo o sentido comum atribuível aos termos do tratado no seu contexto e à luz dos respectivos objeto e fim".

${ }^{78}$ Relatório do Órgão de Recurso no caso Turkey - Restrictions on Imports of Textile and Clothing Products, 22-10-1999, parágrafo 45.
} 


\section{Efeitos dos Blocos Econômicos Regionais}

\subsection{O Critério de Jacob Viner}

Contrariando o argumento geral, até então dado como certo, de que toda a união aduaneira, através da eliminação dos direitos aduaneiros no comércio entre os seus membros, conduziria necessariamente a um aumento do bem-estar para todos os países ${ }^{79}$, Jacob Viner introduziu, em 1950, os conceitos de "criação de comércio" e de "desvio de comércio". No caso do primeiro conceito, temos a passagem de um produtor menos eficiente para um mais eficiente; no caso do segundo, a situação invers ${ }^{80}$. Exemplificando, suponhamos que os custos de produção em três países $(\mathrm{A}, \mathrm{B}$ e $\mathrm{C}$ ) são os seguintes: $\mathrm{A}=30, \mathrm{~B}=25 \mathrm{e} \mathrm{C}=20$, e que os direitos aduaneiros de uma determinada mercadoria são, em todos eles, de 8 . Se os países $\mathrm{A}$ e $\mathrm{B}$ passam a fazer parte de um bloco econômico regional, que não abrange o país $\mathrm{C}$, o país $\mathrm{A}$, que antes importava a mercadoria em causa do país $\mathrm{C}$ (pagando o importador 28 por cada unidade adquirida), passa a importá-la do país B (pagando o importador 25 por cada unidade importada) ${ }^{81}$. A integração econômica pode assim provocar um "desvio

\footnotetext{
79 "The literature on customs unions in general, whether written by economists or non-economists, by free-traders or protectionists, is almost universally favorable to them (...). It is a strange phenomenon which unites freetraders and protectionists in the field of commercial policy". Cf. Jacob Viner, The Customs Union Issue, in Trading Blocs: Alternative Approaches to Analysing Preferential Trade Agreements, Jagdish Bhagwati, Pravin Krishna, and Arvind Panagariya ed., The Massachusetts Institute of Technology Press, 1999, p. 105.

${ }^{80}$ Segundo Victor Calvete, os efeitos criação de comércio e desvio de comércio podem basear-se em três critérios: "um econômico (passagem de um produtor menos eficiente para um mais eficiente [criação] e vice-versa [desvio], e dois literais (aparecimento de comércio onde antes o não havia [criação] e alteração na origem do fluxo comercial [desvio]; ou transferência de produção interna para o país parceiro [criação] e substituição de um produtor de um país terceiro por um produtor do país parceiro [desvio]. A terceira possibilidade considerada por Viner só pode ser reconduzida à criação de comércio desde que se adote o segundo critério referido ( $1^{\circ}$ entendimento literal): a remoção de uma medida anti-sumptuária cria um novo fluxo comercial. É que justamente porque se trata de comércio novo, a comparação de custos de produção em dois momentos distintos (critério econômico) é impossível, e não há transferência de produção interna para o país parceiro ( $2^{\circ}$ entendimento literal ou geográfico) porque na hipótese vineriana não havia produção interna". Cf. Victor Calvete, Sobre a Teoria das Uniões Aduaneiras - sobre o que se disserta, in Boletim de Ciências Econômicas, 2000, p. 525.

${ }^{81}$ Atenção, porém, que o desvio de comércio representa um custo não só para o país exportador que não faz parte do bloco econômico regional (as suas exportações sofrem, pelo menos, uma redução), mas também para o país importador que participa no bloco. De fato, embora os consumidores passem a pagar um preço mais baixo do que anteriormente à criação do bloco, o governo perde as receitas associadas aos direitos aduaneiros que foram eliminados com a criação do bloco econômico regional. Em qualquer caso, o preço pago pelos consumidores será sempre maior do que aquele que resultaria da liberalização comercial a nível multilateral.
} 
de comércio" das fontes de abastecimento mais eficientes exteriores à área integrada (o caso do país $\mathrm{C}$ ), para fontes de abastecimento do interior da área, que, embora sejam as mais eficientes dessa área, são menos eficientes que outras do exterior (o caso do país B).

Note-se, porém, que o efeito de "desvio de comércio" não constitui a contrapartida do efeito de "criação de comércio" (daí a escolha da designação "desvio" e não, por exemplo, "eliminação" ou "supressão"), visto que, enquanto o efeito de "criação de comércio" consiste na criação de um novo fluxo comercial, o efeito de "desvio de comércio" não se traduz na sua eliminação, mas, antes, na modificação da origem de um fluxo comercial existente.

Os efeitos benéficos da união aduaneira (e da zona de comércio livre) serão predominantes se a "criação de comércio" for superior ao "desvio do comércio".

A probabilidade de haver vantagem líquida com a criação de um bloco econômico regional deverá ser tanto maior:

a) quanto maior for o nível dos direitos aplicados anteriormente entre os países membros; b) quanto menor for o nível dos impostos aplicados em relação a terceiros;

c) quanto maior ou, mais concretamente, quanto mais relevante for a parcela do comércio mundial que se dá entre os países que o constituam;

d) quanto maior for o comércio (e outras relações econômicas) entre estes antes da integração;

e) quanto mais concorrenciais (não complementares) forem as economias (v.g. entre países igualmente industrializados); e

f) quanto maior for a proximidade geográfica (sendo mais baixos os custos de transporte) ${ }^{82}$.

Alguns autores defendem também que a liberalização do comércio verificada no interior dos blocos econômicos regionais, mesmo se acompanhada de um "desvio de comércio", pode gerar ganhos para os países afetados. Com efeito, os ajustamentos internos ligados à liberalização regional permitem que as economias dos países membros dos blocos se tornem mais competitivas e melhor preparadas para aceitar, econômica e politicamente, a liberalização comercial multilateral; o aumento da concorrência na região e a redução global dos custos de produção permitem ensaiar uma maior agressividade nos mercados mundiais e abrir mais facilmente os mercados regionais aos produtores estrangeiros; os consumidores passam a ter acesso a produtos mais baratos, o que se traduz num aumento do bem-estar; e para países terceiros, se a zona de integração se caracterizar,

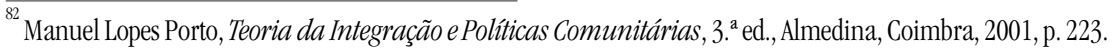


como é normal, por um maior crescimento econômico, pode também haver vantagens, em conseqüência do aumento das importaçōes de países não membros (verifica-se, então, o que alguns autores apelidam de external trade (reation) ${ }^{83}$.

\subsection{Building Blocks ou Stumbling Blocks?}

Em relação aos efeitos dos blocos econômicos regionais propriamente ditos sobre o sistema comercial multilateral, concluímos em estudo anterior que, apesar de alguns problemas na observância do art. XXIV do GATT, os blocos existentes têm constituído uma via alternativa de liberalização do comércio mundial, isto é, têm constituído para o processo de liberalização comercial multilateral mais um complemento do que uma ameaça, mais um reforço do que um desincentivo ${ }^{84}$. Basta ver que o regionalismo avançou a par da continuada liberalização comercial alcançada a nível multilateral, o que resultou numa redução contínua da diferença entre as tarifas "nação mais favorecida" e as tarifas preferenciais dos blocos econômicos regionais. A criação da Comunidade Européia e os sucessivos alargamentos, por exemplo, encorajaram sempre os países estranhos à construção européia a promover negociações comerciais multilaterais sob a égide do GATT: nas negociações do Ciclo de Dillon e do Ciclo de Kennedy, o objetivo foi o de reduzir a margem de discriminação diminuindo a incidência média da pauta aduaneira comum da Comunidade Econômica Européia; no Ciclo de Tóquio, o alargamento da Comunidade à Dinamarca, ao Reino Unido e à Irlanda e a incidência da política agrícola comum sobre os países terceiros estiveram na sua origem; e o Ciclo do Uruguai, cujo lançamento se encontrava em stand-by desde 1982, ganhou um impulso decisivo com a apresentação do programa do mercado interno em 1985.

\footnotetext{
${ }^{83} \mathrm{OMC}$, Le régionalisme et le système commercial mondial, pp. 50-51.

${ }^{84}$ Pedro Infante Mota, Os Blocos Econômicos Regionais e o Sistema Comercial Multilateral. O Caso da Comunidade Européia , in Revista da Faculdade de Direito da Universidade de Lisboa, vol. XL, n. ${ }^{\circ} 1$ e 2, 1999, pp. 71-156. o MERCOSUL, constituído pelo Brasil, Argentina, Uruguai e Paraguai, e considerado o mais importante dos blocos econômicos regionais entre países em desenvolvimento, parece constituir a exceção mais significativa (cf. Alexander J. Yeats, Does Mercosur's Trade Performance Raise Concerns about the Effects of Regional Trade Arrangements?, in The World Bank Economic Review, vol. 12, n. ${ }^{\circ}$ 1, 1998, pp. 1-28). De fato, segundo Roberto Echandi, "the importance of the intra-sub-regional market as an export destination has increased not only in absolute terms, but also relative to other extra-regional trade partners. (... While in 1990 the countries of MERCOSUR only used to receive 9 percent of their total exports, in 1998 they bought 25 percent. Between 1990 and 1998, after having been the fourth destination in importance for its member countries, MERCOSUR became the most important market for its own exports. MERCOSUR is the only example in which an Regional Trade Agreement seems to have led to a transformation of the trade structure of its member countries". Cf. Roberto Echandi, Regional Trade Integration in the Americas ..., p. 383.
} 
No que diz respeito ao principal critério de aferição dos efeitos dos blocos econômicos regionais, o critério de Jacob Viner ${ }^{85}$, a liberalização do comércio mundial levada a cabo em sucessivas negociaçôes comerciais multilaterais tem reduzido a amplitude do risco de "desvio de comércio" que os blocos comportam, além de que a sua utilidade é algo relativa no atual contexto de globalização econômica (o comércio intra-ramo que predomina nos países industrializados assenta na concorrência imperfeita e em economias de escala) ${ }^{86}$.

Para a maioria dos blocos econômicos regionais, valem ainda três aspectos particularmente importantes, a saber:

I) desde finais da II Guerra Mundial, as taxas de crescimento do comércio externo superaram, no total, as taxas de crescimento da produção, ou seja, as economias tornaram-se mais abertas para o exterior ${ }^{87}$;

II) apesar dos resultados positivos, a maioria dos estudos empíricos não tem em conta o impulso potencial que é dado às exportaçôes dos países terceiros devido ao aumento da taxa de crescimento econômico nos países participantes no bloco econômico regional ${ }^{88} ; \mathrm{e}$

\footnotetext{
85 "this static analysis has, generally, been the mainstay of Regional Trade Agreements assessments by economists for the past 50 years". Cf. Gabrielle Marceau e Cornelis Reiman, When and How Is a Regional Trade Agreement ..., p. 304. ${ }^{86}$ Peter Lloyd, Regionalisation and World Trade, OCDE Economic Studies n. ${ }^{\circ}$ 18, 1992, p. 24. Por exemplo, 0 comércio intra-ramo entre os EUA e a Comunidade Européia representava, em 1995, 57\% do comércio total entre os dois maiores global traders da actualidade. Cf. Comissão das Comunidades Européias, Report on United States Barriers to Trade and Investment, Bruxelas, Julho de 2000, p. 4.

${ }^{87}$ Entre 1948 e 1997, as exportações de mercadorias cresceram 6\% ao ano, em termos reais, ao passo que a produção cresceu 3,7\% ao ano. Cf. OMC, Annual Report 1998, p. 33.

Isso explica serem raros os casos em que se verifica uma redução absoluta das importações originárias de países terceiros, salvo nos casos em que os obstáculos às importações são importantes, como acontece com os produtos agrícolas. No caso da Comunidade Econômica Européia, Manuel Lopes Porto observa que, "tendo duplicado o PNB (entre 1958 e 1993), aumentou o relevo relativo do comércio, passando a representar 18\% desse valor em 1993, quando representava $10 \%$ em 1958. (...) Neste maior crescimento foi naturalmente mais relevante o crescimento do comércio intra-bloco, com um relevo em relação ao produto que mais do que duplicou (passou de 4 para 9\% do PNB); mas não deixou de aumentar o relevo do comércio extra-bloco, passando de 6 para 9\% do PNB" (cf. Manuel Lopes Porto, Os blocos regionais e o comércio mundial, in Estudos Jurídicos e Econômicos em Homenagem ao Professor João Lumbrales, Edição da Faculdade de Direito da Universidade de Lisboa, Coimbra Editora, 2000, pp. 706-707). Finalmente, é preciso atender ao fato de uma redução das importações do resto do mundo não indicar necessariamente que há desvio de comércio. Suponhamos, por exemplo, que o país A é um produtor mais eficiente que o país $\mathrm{C}$, mas que uma quota restringe as exportações do país A para o país $\mathrm{B}$, pelo que este satisfaz as suas necessidades comprando bens do país C. Logo, um acordo de comércio livre entre os países A e B que elimine a quota permitirá ao país A aumentar as suas vendas à custa do país $\mathrm{C}$, mas isto, atenção, representa "criação do comércio" e não "desvio do comércio".
} 
(III) tendo os custos de transporte e de comunicação influência na intensidade dos fluxos comerciais e no preço dos bens, permitindo nomeadamente a manutenção de produtores nacionais marginais no mercado ${ }^{89}$, é natural que os países estabeleçam relaçōes comerciais principalmente com os seus países vizinhos ou, pelo menos, com os países mais próximos em termos geográficos (são os chamados "blocos comerciais naturais", fenômeno também conhecido por regional regionalism $)^{90}$.

${ }^{89}$ No caso do comércio internacional, os custos do transporte excedem, regra geral, o valor dos direitos aduaneiros (cf. Jeffrey Frankel, Regional Trading Blocs in the World Economic System, Institute for International Economics, Washington, D.C., 1997, p. 41), e estima-se que o aumento da distância entre dois países em 1\% implique uma diminuição do comércio entre ambos de 1\% (cf. Jeffrey Frankel, Assessing the Efficiency Gains from Further Liberalization, in Efficiency, Equity, and Legitimacy: The Multilateral Trading System at the Millennium, Roger Porter, Pierre Sauvé, Arvind Subramanian e Americo Zampetti ed., Brookings Institution Press, Washington, D.C., 2001, p. 84) e que dois países que partilham uma fronteira comum apresentem um volume de comércio superior em $82 \%$ ao realizado entre dois países similares, mas distantes geograficamente (cf. Jeffrey Frankel, Regional Trading Blocs..., p. 71). No entanto, as relações comerciais entre alguns países vizinhos, como a Índia e o Paquistão, o Irão e o Iraque, Israel e a Síria são pouco importantes face ao que se poderia esperar da sua proximidade geográfica e claramente prejudicadas pela existência de conflitos, atuais ou potenciais, entre si. Por exemplo, no caso da Índia e do Paquistão, o comércio entre os dois países é inferior em 70\% ao verificado entre dois países com um peso econômico idêntico ao seu (cf. idem, p. 116) e no caso do médio-oriente, em 1993, apenas 6\% do comércio na região era entre países vizinhos (cf. Ariel Ezrahi, Opting Out of Opt-Out Clauses: Removing Obstacles to International Trade and International Peace, in Law \& Policy in International Business, vol. 31, n. ${ }^{\circ}$ 1, 1999, p. 152). Tem sido assinalado, ainda, que o comércio entre países aliados é, em média, superior em $140 \%$ ao comércio realizado entre países não aliados, ou seja, as alianças influenciam os fluxos comerciais, visto que o comércio internacional, ao gerar ganhos de eficiência, aumenta o poder político-militar dos países aliados e, em conseqüência, a sua segurança. Cf. Edward D. Mansfield e Rachel Bronson, The Political Economy of Major-Power Trade Flows, in The Political Economy of Regionalism, Edward D. Mansfield e Helen V. Milner ed., Columbia University Press, Nova Iorque, 1997, pp. 188-208.

${ }^{90}$ A este respeito, uma ressalva importante deve ser feita: ter em conta, por exemplo, que, embora a distância entre a Austrália e a Nova Zelândia seja igual à distância entre a Espanha e a Polônia, é natural que o comércio entre os dois países da Oceania seja superior ao realizado entre os dois países europeus, pela simples razão de que os primeiros não têm, situados à mesma distância geográfica, outros parceiros "naturais" com que estabelecer relações comerciais. Em sentido contrário à hipótese dos chamados "blocos comerciais naturais", temos a opinião de Arvind Panagariya e T. Srinivasan, que defendem que "natural trading partners hypothesis has no analytical basis. Among other things, (...) a large initial volume of trade says nothing about how a tariff preference will affect trade flows at the margin, which is what trade diversion is about. (...) The natural trading partnership is neither symmetric nor transitive. For example, the US, which is a neighbour of Mexico and with which it trades a lot, may be a natural trading partner of Mexico. But the reverse may not be true since trade with Mexico does not dominate the trade of the US. Similarly, the US may be a natural trading partner of both Mexico and Canada, but Mexico and Canada may not be natural trading partners" (cf. Arvind Panagariya e T. Srinivasan, The New 
Num outro plano, é importante ter presente que os blocos econômicos regionais devem a sua criação, por vezes, a motivos políticos ${ }^{91}$. Na própria visão dos founding fathers do GATT, livre-cambismo e multilateralismo não eram apenas uma necessidade econômica, mas igualmente política, e os EUA, então o principal mentor do sistema comercial multilateral, mostraram-se muito favoráveis à criação da Comunidade Européia, entendendo que a coesão política da Europa ocidental, face ao expansionismo soviético, era bem mais importante que a simples dimensão comercial $^{92}$.

Regionalism: a Benign or Malign Growth?, in The Uruguay Round and Beyond: Essays in Honour of Arthur Dunkel, Springer, 1998, p. 225). Finalmente, não podemos deixar de realçar que, apesar de tradicionalmente a formação de blocos econômicos regionais ter ocorrido entre países geograficamente contíguos, entre países com relações comerciais entre si já bem desenvolvidas (a zona de comércio livre entre a Austrália e a Nova Zelândia, o NAFTA, a Comunidade Européia e a EFTA são bons exemplos), os acordos de criação de blocos econômicos regionais são cada vez mais celebrados entre países geograficamente não contíguos, pelo que o termo "regional" tende a perder significado. Outro fenômeno interessante que se regista atualmente éo que se prende com a emergência de uma nova categoria de acordos: blocos econômicos regionais em que as partes são elas próprias blocos econômicos regionais (por exemplo, está-se a negociar presentemente um acordo de associação entre a Comunidade Européia e o MERCOSUL).

${ }^{91}$ Em 1889, Vilfredo Pareto defendia já que "customs unions (...) were (...) a means to better political relations and eventual pacification" (citado in Fritz Machlup, A History of Thought ..., p. 41). Em alguns casos, porém, a criação de um bloco econômico regional pode degenerar num aumento da insegurança entre os territórios que o constituem. O exemplo clássico é o dos EUAno século XIX, os quais, ao cobrarem elevadas tarifas sobre os produtos manufaturados, protegendo a sua indústria, constituíram a grande exceção ao movimento de liberalização comercial que se verificou depois da celebração do Tratado Cobden-Chevalier em 1860. 0 Norte era então bem mais desenvolvido que o Sul, produzindo e exportando para este último produtos manufaturados, enquanto que o Sul exportava produtos agrícolas. Situando-se muita da indústria norte-americana no Norte do país, tal implicava que o setor agrícola, concentrado no Sul, era obrigado a transferir efetivamente uma parte do seu rendimento para o Norte, visto que era forçado a pagar mais pelos bens de equipamento e de consumo de que necessitava. Não admira, pois, que esta tenha sido uma das razões que levaram o Sul a pretender sair da União (cf. Bernard Hoekman e Michel Kostecki, The Political Economy of the World Trading System: The WTO and Beyond, 2. ${ }^{a}$ ed., Oxford University Press, 2001, p. 23; Bernard Hoekman e Maurice Schiff, Benefiting from Regional Integration, in Development, Trade, and the WTO: A Handbook, Bernard Hoekman, Aaditya Mattoo e Philip English ed., The World Bank, Washington, D.C., 2002, p. 555). Finalmente, é evidente que os objetivos prosseguidos pelos blocos econômicos regionais não têm de se limitar necessariamente aos aspectos econômicos e políticos. No caso do NAFTA, por exemplo, um dos seus objetivos principais passa por refrear os fluxos de emigração ilegal, objetivo igualmente presente nos acordos de associação celebrados entre a Comunidade Européia e alguns países da Europa de Leste.

${ }_{92}$ Nas palavras de Robert e. Hudec, "the EEC was the cornerstone of a new North Atlantic foreign policy, as important as GATT". Cf. Robert E. Hudec, The GATT Legal System and World Trade Diplomacy, Praeger Publishers, Nova Iorque-Washington, Londres, 1975, p. 196. 
Por fim, merece atenção o fato de a existência de alguns blocos econômicos regionais implicar, necessariamente, uma maior segurança e facilidade na condução do comércio. $\mathrm{Na}$ Comunidade Européia, por exemplo, com a harmonização atingida, o exportador ou investidor estrangeiro, em princípio, não têm de conhecer e adaptar-se a requisitos diferentes, variáveis de país para país, podendo ter acesso a todos eles com a observância das mesmas regras, o que facilita a obtenção de economias de escala. A própria criação da moeda única, o euro, vai nesse sentido. Ao mesmo tempo, os blocos econômicos regionais têm permitido desenvolver disciplinas que são depois aproveitadas pelo sistema comercial multilateral (o caso dos serviços, das compras públicas e dos obstáculos técnicos ao comércio) e abordar assuntos que constam da agenda futura da Organização Mundial do Comércio (o caso das práticas comerciais restritivas). No primeiro caso, por exemplo, o importante princípio do reconhecimento mútuo, fundamental na construção do mercado interno ${ }^{93}$, encontra-se agora consagrado no art. $4^{\circ}, \mathrm{n}^{\circ} 1$, do Acordo sobre Medidas Sanitárias e Fitossanitárias ${ }^{94}$ e é manifesta a influência do art. $92^{\circ}$ do Tratado de Roma e

\footnotetext{
${ }^{93}$ Segundo o princípio do reconhecimento mútuo, aplicável na Comunidade Européia, os Estados-membros devem aceitar a comercialização no seu território das mercadorias legalmente produzidas e postas em circulação em qualquer outro Estado-membro, salvo se puderem invocar exigências imperativas decorrentes de uma regulamentação nacional (na ausência de regulamentação comum ou harmonizada na matéria em causa), aplicável indistintamente aos produtos nacionais e aos produtos importados. Este princípio mantém-se mesmo que tais mercadorias sejam fabricadas segundo prescrições técnicas diferentes das impostas pelas regulamentações internas do Estado de importação, desde que os produtos em causa correspondam de forma satisfatória ao objetivo legítimo que estas regulamentações têm em vista (cf. Acórdão do Tribunal de Justiça das Comunidades Européias, de 20-2-1979, Cassis de Dijon, Proc. 120/78, Col. 1979, p. 649, considerando n. 8 (p. 662)). Como é evidente, o princípio do reconhecimento mútuo, no caso comunitário, permite aos exportadores estrangeiros economias consideráveis, visto não ser necessário a adaptação às particularidades dos mercados dos diversos Estados-membros.

${ }^{94}$ Paul Demaret, The Metamorphoses of the GATT: From the Havana Charter to the World Trade Organization, in Columbia Journal of Transnational Law, vol. 34, n. ${ }^{0} 1,1995$, p. 153. Segundo a disposição em causa, "os membros aceitarão as medidas sanitárias ou fitossanitárias de outros membros como equivalentes, mesmo que difiram das suas ou das que são utilizadas por outros membros que se dediquem ao comércio do mesmo produto, se o membro exportador demonstrar objetivamente ao membro importador que, com as suas medidas, é atingido o nível adequado de proteção sanitária ou fitossanitária no membro importador. Para o efeito, será facultado ao membro importador que o solicite um acesso razoável para a realização de inspeções, ensaios e outros procedimentos pertinentes". De notar, ainda, que no art. $6{ }^{\circ}$, n. $^{0} 3$, do Acordo sobre os Obstáculos Técnicos ao Comércio se encoraja os membros "a estabelecer negociações com vista à conclusão de acordos de reconhecimento mútuo" e que, nos termos do art. 2. n. ${ }^{0} 7$, do mesmo Acordo, "os membros considerarão favoravelmente a possibilidade de reconhecer como equivalentes os regulamentos técnicos de outros membros, mesmo se tais regulamentos forem diferentes dos seus, desde que tenham a certeza de que esses regulamentos satisfazem os objetivos dos seus próprios regulamentos".
} 
da jurisprudência do Tribunal de Justiça das Comunidades Européias sobre o novo Acordo sobre as Subvençōes e as Medidas de Compensação saído do Ciclo do Uruguai ${ }^{95}$. No segundo caso, é de realçar que, em Maio de 1996, dos 22 acordos regionais em análise pelos grupos de trabalho da Organização Mundial do Comércio, 19 continham disposiçôes em matéria de política de concorrência e 8 lidavam com o investimento estrangeiro, ambas matérias ainda não regulamentadas a nível multilateral ${ }^{96}$.

\section{O Óptimo de Pareto}

Não obstante o regionalismo estar na moda, é indubitável que, em termos econômicos, só teremos uma solução de primeiro óptimo, ou de óptimo de Pareto, com o comércio livre mundial. Só se este existir, será seguro, segundo Manuel Lopes Porto, que:

“se disporá então necessariamente - e só então - do bem pelo menor preço possível. É essa, pois, a solução do primeiro óptimo, sendo as soluçōes de formação de uniōes aduaneiras apenas soluçôes menos favoráveis, de segundo óptimo, dado que pode sempre estar de fora algum país com um preço mais baixo. (...) Num mercado comum mundial estarão disponíveis todos os fatores de produção existentes, incluindo necessariamente os fatores dos países onde o seu preço for mais baixo" ${ }^{97}$.

Dadas as vantagens associadas ao comércio livre multilateral, várias propostas de melhoria das atuais regras do art. XXIV do GATT têm sido avançadas. Importa, sobretudo, evitar que países terceiros não abrangidos pelos blocos econômicos regionais sejam lesados e as barreiras nacionais ao comércio internacional substituídas por barreiras regionais.

Em relação às uniōes aduaneiras, propôe-se que o seu estabelecimento deve ser acompanhado de uma redução dos obstáculos às importações de mercadorias originárias de países terceiros, o que pode ser atingido impondo que a tarifa mais baixa aplicada entre os

\footnotetext{
${ }^{95}$ Thiébaut Flory, La mise en place d'un nouveau système commercial multilatéral, in La Communauté Européenne et le GATT. Évaluation des accords du cycle d'Uruguay, direction de Thiébaut Flory, Éditions Apogée, 1995, pp. 18-19.

${ }^{96}$ Gary Sampson, Compatibility of Regional and Multilateral Trading Agreements: Reforming the WTO Process, in American Economic Association Papers and Proceedings, vol. 86, n. ${ }^{\circ}$ 2, 1996, p. 89.

${ }^{97}$ Manuel Lopes Porto, Teoria da Integração e Políticas Comunitárias, 2001, pp. 236-237. No mesmo sentido, James Meade observa que "a union between all the countries of the world could not lead to any import or export trade diversion". Cf. James Meade, The Theory of Customs Unions, North-Holland Publishing Company, Amesterdã, 1955, p. 109.
} 
países participantes a um produto antes do estabelecimento da união se transforme na tarifa aduaneira comum para o produto em causa ${ }^{98}$.

No que diz respeito às zonas de comércio livre, a probabilidade de elas serem prejudiciais prende-se, essencialmente, com a administração das regras de origem ${ }^{99}$. Nas zonas de comércio livre não existe uma pauta aduaneira comum, pelo que os direitos aduaneiros diferem, geralmente, de um membro para outro e daí os exportadores situados num país terceiro terem todo o interesse em entrar na zona através do mercado do membro que tem os direitos aduaneiros mais reduzidos ("efeito deflector do comércio"). Para evitar que tal aconteça, os membros da zona de comércio livre adotam regras de origem, destinadas a determinar se uma mercadoria que entra num país membro foi produzida ou não na zona, visto que só as mercadorias aí produzidas gozarão de um tratamento preferencial, que se traduz no não pagamento de direitos aduaneiros quando da circulação no seu interior $^{100}$. Assim sendo, pode acontecer que um produtor de um país membro de uma

\footnotetext{
${ }^{98}$ Jagdish Bhagwati, Regionalism and multilateralism: an overview, in New Dimensions in Regional Integration, Jaime de Melo e Arvind Panagariya ed., Centre for Economic Policy Research, Cambridge University Press, 1993, p. 36; 0MC, Le regionalisme et le système commercial mondial, p. 77; Jaime Serra et al., Reflections on Regionalism ..., p. 12; Michael Trebilcock e Robert Howse, The Regulation of International Trade, 2. ${ }^{\mathrm{a}}$ ed., Routledge, Londres e Nova Iorque, 1999, p. 428. Em relação a esta proposta, Sung-Hoon Park nota que "adopting this rule would make countries with low tariffs less attractive partners for a Customs Union, and would thus lead to a reduction in the number of Regional Integration Agreements. However, high-tariff countries will also be inclined to form customs unions, strengthening the trade diversion effect". Cf. Sung-Hoon Park, Regionalism, Open Regionalism and Article XXIV GATT: Conflicts and Harmony, in Regional and Global Regulation of International Trade, Francis Snyder ed., Hart Publishing, Oxford-Portland Oregon, 2002, p. 279.

${ }^{99}$ De acordo com o art. $1^{0}, n^{0}{ }^{1}$, do Acordo sobre Regras de Origem, as regras de origem são definidas como "as disposições legislativas e regulamentares e as decisões administrativas de aplicação geral que sejam aplicadas por qualquer um dos membros para determinar o país de origem das mercadorias". Este Acordo, adoptado no Ciclo do Uruguai, só se refere às regras de origem preferenciais no seu anexo II ("Declaração Comum Relativa às Regras de Origem Preferenciais"). Segundo RobertE. Hudec eJames D. Southwick, as regras de origem não constituem regulamentações no sentido do art. XXIV, n. ${ }^{\circ}$, alínea b), do GATT. Isto porque, antes da criação de uma zona de comércio livre, "there obviously are no rules of origin for the preferential regional trade tariffs of that agreement, because those preferential tariffs do not yet exist" (cf. RobertE. Hudec eJames D. Southwick, Regionalism and WTO Rules ...,pp. 56-57). Mas, por exemplo, será queélícito que os membros de um bloco econômico regional estabeleçam uma regra de origem a determinar que só os produtos inteiramente obtidos no seu território beneficiam do tratamento preferencial?

${ }^{100}$ Moshe Hirsch defende que, no caso de não serem adoptadas quaisquer regras de origem, o mais provável é que o "efeito deflector do comércio" pressione os países com direitos aduaneiros mais elevados a procederem à sua redução, aproximando-os do país com os direitos aduaneiros mais baixos, e formando, de fato, uma união aduaneira. Cf. Moshe Hirsch, International Trade Law, Political Economy and Rules of Origin: A Plea for a Reform of the WTO Regime on Rules of Origin, in Journal of World Trade, 2002, p. 176.
} 
zona de comércio livre prefira importar um produto intermediário de um país igualmente membro da zona, pagando mais do que pagaria se o importasse de um país terceiro ${ }^{101}$, visto o produto final só gozar do tratamento preferencial se uma determinada percentagem dos seus componentes for produzida no seu interior ${ }^{102}$.

${ }^{101}$ Como bem observam Antoni Estevadeordal e Kati Suominem, "as such, Rules of Origin liken a tariff on the intermediate product levied by the importing country". Cf. Antoni Estevadeordal e Kati Suominem, Rules of Origin in the World Trading System, Paper Prepared for the Seminar on Regional Trade Agreements \& the WTO, World Trade Organization, 14-11-2003 [http://www.wto.org], p. 3.

${ }^{102}$ Em compensação, as zonas de comércio livre oferecem maior margem de manobra aos países que desejam liberalizar o seu comércio face a países terceiros, uma vez que tal liberalização não exige o acordo de todos os países que façam parte da Zona. No caso das uniões aduaneiras, pelo contrário, a pauta aduaneira comum só pode sofrer alterações se todos os países participantes em cada União anuírem. Em qualquer caso, considera-se que nos blocos econômicos regionais é mais difícil aos grupos de pressão defenderem posições protecionistas, visto que, ao mesmo tempo que aumenta o espaço econômico, aumenta também a dificuldade dos grupos nacionais de influírem no "desenho" das políticas comuns (é o chamado preference-dilution effect), embora também se diga que, sendo natural que os grupos de produtores nacionais se encontrem já bem organizados, o custo da sua cooperação a nível regional não será muito elevado. Apesar disso, é normal que as preferências dos diversos países membros sobre certas matérias varie, o que torna mais difícil a obtenção de compromissos (éo chamado preferenceasymmetry effect, ultrapassado nalguns casos, no entanto, pelo chamado fenômeno do log-rolling), e que a concorrência acrescida no interior do bloco elimine um grande número de empresas ineficazes, o que reduzirá os pedidos de proteção (cf. Bernard Hoekman e Michael Leidy, Holes and Loopholes in Integration Agreements: History and Prospects, Centre for Economic Policy Research Discussion Paper n. ${ }^{7}$ 748, 1992). 0 fenómento do logrolling ocorre quando o apoio a uma determinada medida protecionista proposta por um país, ou por vários, é "comprado" através da promessa aos países relutantes de apoio noutras matérias do seu interesse específico. Por exemplo, de acordo com Sanoussi Bilal, "the potential protectionist follies of log-rolling are probably best illustrated by the Smoot-Hawley Tariff Act adopted by US Congress in 1930. (...) That is, to achieve broad political support in favor of protection for industries in their constituency, congressmen do not oppose protection for industries in other districts. An interesting feature of this process, particularly salient in the case of the Smoot-Hawley Act, is the tendency towards a generalization of protection to all sectors in the economy. As a result, the legislation instead of being exclusive has become hospitable and almost universal" (cf. Sanoussi Bilal, Political Economy Considerations on the Supply of Trade Protection in Regional Integration Agreements, in Journal of Common Market Studies, 1998, p. 6). A adoção pelos EUA, em Junho de 1930, da célebre Smoot-Hawley Tariff, que elevou de 38.2 para $55.3 \%$ o nível médio dos direitos aduaneiros cobrados pelas autoridades norte-americanas resultou num agravamento da depressão econômica ocorrida no ano anterior e uma autêntica corrida ao protecionismo: os direitos aduaneiros sofreram aumentos em vários países, muitos países passaram a recorrer a controlos cambiais e a restrições quantitativas e a Grã-Bretanha, até então a maior potência econômica e grande defensora do livre-cambismo, estabelecia, em Fevereiro de 1932, a sua primeira pauta aduaneira geral desde meados do século XIX, iniciando-se, meses depois, a 21 de Julho de 1932, a Conferência Econômica Imperial de Ottawa que culminaria com a extensão do regime da preferência imperial a todos os países e territórios da Commonwealth. 0 regime da preferência imperial implicava que, em primeiro lugar, estavam os produtos 
A administração das regras de origem impõe, por outro lado, custos de transação adicionais aos agentes que procuram demonstrar que satisfazem as regras estabelecidas e, não existindo regras multilaterais disciplinadoras das regras de origem preferenciais, a extraordinária variedade e muitas vezes complexidade dessas regras dificultam em muito a vida aos agentes econômicos ${ }^{103}$. A crescente divisão do trabalho a nível mundial tem ajudado, por último, a tornar a problemática das regras de origem ainda mais complexa ${ }^{104}$. Por todas estas razões, Jagdish Bhagwati defende que apenas as uniões aduaneiras devem ser admitidas como exceção à cláusula da nação mais favorecida ${ }^{105}$.

É de notar, por último, que o México, na seqüência da crise do peso em 1994/95, aumentou, sem violar quaisquer consolidaçôes feitas por si no âmbito do GATT, os seus direitos aduaneiros relativamente a 503 produtos importados de países não-membros do

nacionais, em segundo lugar, os produtos originários do Império Britânico e, por último, os produtos originários de territórios que não pertencessem à Comunidade Britânica de Nações. Segundo Richard Pomfret, "the deterioration in foreign countries' access to British Empire markets was striking. In 1930 over four-fifths of imports from foreign (i.e. non-Empire) countries entered the UK duty-free, whereas after the Ottawa Conference the proportion was reduced to a quarter". Cf. Richard Pomfret, The Economics of Regional Trading Arrangements, p. 56.

${ }^{103}$ Por exemplo, no caso da EFTA, o custo de obtenção dos documentos necessários para provar a origem dos produtos foi estimado em cerca de 3 a 5\% do preço f.o.b. (cf. Anne Krueger, Free Trade Agreements versus Customs Unions, National Bureau of Economic Research Working Paper n. ${ }^{\circ}$ 5084, 1995, p. 15); na Europa, os custos de recolha, tratamento e armazenamento da informação necessária à verificação da origem foram calculados em cerca de 3\% do preço dos produtos (cf. Luis Jorge Garay e Rafael Cornejo, Rules of Origin in Free Trade Agreements in the Americas, in Trade Rules in the Making: Challenges in Regional and Multilateral Negotiations, Miguel Rodríguez Mendoza, Patrick Low e Barbara Kotschwar ed., Organization of American StatesBrookings Institution Press, Washington, D.C., 1999, pp. 263-264); no caso do NAFTA, a problemática das regras de origem ocupa 194 páginas do Acordo (cf. Jeffrey Frankel, Regional Trading Blocs ..., p. 14); e, em 1994, a Comunidade Européia dispunha de 14 sistemas de regras de origem preferenciais diferentes e os EUA de 6 sistemas. Cf. Gary Sampson, Compatibility of Regional and Multilateral Trading Agreements ..., p. 89; Jaime Serra et al., Reflections on Regionalism ..., p. 46.

${ }^{104}$ Peter Lloyd, Country of origin in the global economy, in World Trade Review, 2002, pp. 171-185.

${ }^{105}$ Jagdish Bhagwati, The Threats to the World Trading System, in The World Economy, 1992, p. 455. Segundo Jagdish Bhagwati, "free Trade Areas are two-faced: they free trade and they retreat into protection, simultaneously. (... So, since clearly the phrase Free Trade Area is calculated to confuse it with free trade, I have urged over the years, with some success, that economists call Free Trade Areas by the phrase Preferential Trade Areas, which, at minimum, alerts the public and the politicians to the fact that here we have another species" (cf. Jagdish Bhagwati, Free Trade Today, Princeton University Press, Princeton e 0xford, 2002, p. 107). Apesar disso, em Outubro de 2003, as uniões aduaneiras representavam somente $7 \%$ de todos os blocos econômicos regionais criados. Cf. Clemens Boonekamp, The Changing Landscape of RTAs, Seminar on Regional Trade Agreements and the WTO, 14-112003, in http://www.wto.org, parágrafo 10. 
NAFTA $^{106}$. Por conseguinte, seria da maior utilidade que os membros dos blocos econômicos regionais consolidassem os respectivos direitos aduaneiros nos montantes efetivamente cobrados quando da negociação do acordo de comércio livre, o que asseguraria que os obstáculos pautais relativamente a países terceiros não sofressem qualquer agravamento no futuro ${ }^{107}$.

\section{Bibliografia}

\section{ACORDO GERAL SOBRE PAUTAS ADUANEIRAS E COMÉRCIO (GATT)}

Article XXIV of the General Agreement - Note by the Secretariat (MTN.GNG/NG7/W/ 13), 11-8-1987.

Article XXIV of the General Agreement - Note by the Secretariat (MTN.GNG/NG7/W/ 13/Add. 1), 10-8-1988.

Analytical Index: Guide to GATT Law and Practice (ed. Frieder Roessler), 6. ${ }^{\mathrm{a}}$ ed., Genebra, 1994.

\section{ÁREA DE LIVRE COMÉRCIO DAS AMÉRICAS}

Minuta do Acordo ALCA, in http://www.ftaa-alca.org, 2002.

BALDWIN, Richard. The Causes of Regionalism, In: The World Economy, 1997, pp. 865-888.

\footnotetext{
${ }^{106}$ Banco Mundial, Trade Blocs, 2001, in www.worldbank.org/trade, p. 95. Ainda segundo a Comunidade Européia, o México procedeu, em 29 de Dezembro de 1993, à revisão da sua legislação aduaneira com o objetivo de passar a aplicar 0 valor CIF como base da avaliação aduaneira das importações originárias de países não pertencentes ao NAFTA e o valor FOB para as importações originárias dos EUA e Canadá. Antes da revisão, o México aplicava 0 valor FOB a todas as importações. Para a Comunidade, tal comportamento por parte do México pode bem constituir uma violação do art. XXIV, n. ${ }^{0}$ 5, alínea b), do GATT. Cf. OMC, Mexico - Customs Valuation of Imports, Request for Consultations by the European Communities (WT/DS53/1, G/L/105), 9-9-1996.

${ }^{107}$ É verdade que o Memorando de Interpretação do Artigo XXIV do GATT de 1994 nada diz sobre quais os direitos aduaneiros a ter em conta no caso das zonas de comércio livre, falando o art. XXIV, n. ${ }^{\circ}$ 5, alínea $b$ ), do GATT unicamente em “correspondentes”. Não há, no entanto, nenhuma razão para diferenciar as uniões aduaneiras das zonas de comércio livre, pelo que a comparação deve ser feita tendo em conta, quando não coincidam, os direitos aduaneiros efetivamente cobrados e não os direitos consolidados.
} 
BALDWIN, Richard. A Domino Theory of Regionalism, In: Trading Blocs: Alternative Approaches to Analysing Preferential Trade Agreements, Jagdish Bhagwati, Pravin Krishna e Arvind Panagariya ed., The Massachusetts Institute of Technology Press, 1999, pp. 479-502.

\section{BANCO MUNDIAL}

Trade Blocs, 2001, in http://www.worldbank.org/trade.

BHAGWATI, Jagdish. The Threats to the World Trading System, In: The World Economy, 1992, pp. 443-456.

BHAGWATI, Jagdish. Regionalism and multilateralism: an overview, In: New Dimensions in Regional Integration, Jaime de Melo e Arvind Panagariya ed., Centre for Economic Policy Research, Cambridge University Press, 1993, pp. 22-51.

BHAGWATI, Jagdish Free Trade Today. Princeton e Oxford: Princeton University Press, 2002. BHAGWATI, Jagdish e PANAGARIYA, Arvind. Preferential Trading Areas and Multilateralism: Strangers, Friends, or Foes?, In: Trading Blocs: Alternative Approaches to Analysing Preferential Trade Agreements, Jagdish Bhagwati, Pravin Krishna e Arvind Panagariya ed., The Massachusetts Institute of Technology Press, 1999, pp. 33-100.

BILAL, Sanoussi. Political Economy Considerations on the Supply of Trade Protection in Regional Integration Agreements, In: Journal of Common Market Studies, 1998, pp. 131.

BLACKHURST, Richard e HENDERSON, David. Regional Integration Agreements, World Integration and the GATT, In: Regional Integration and the Global Trading System, Kym Anderson e Richard Blackhurst ed., Harvester Wheatsheaf, 1993, pp. 408-435.

BOONEKAMP, Clemens. Regional Trade Integration Under Transformation, Paper Prepared for the Seminar on Regionalism and the WTO, 26-4-2002, in http:// www.wto.org

BOONEKAMP, Clemens. The Changing Landscape of RTAs, Paper Prepared for the Seminar on Regional Trade Agreements and the WTO, 14-11-2003, in http:// www.wto.org

BOUZAS, Roberto. Regional Trade Arrangements: Lessons from Past Experiences, in Trade Rules in the Making: Challenges in Regional and Multilateral Negotiations, Miguel Rodríguez Mendoza, Patrick Low e Barbara Kotschwar ed. Washington, D.C.: Organization of American States-Brookings Institution Press, 1999, pp. 180-202.

CALVETE, Victor. Sobre a Teoria das Uniōes Aduaneiras - Introdução: sobre o que não se disserta, In: Boletim de Ciências Económicas, 1999, pp. 153-244. 
CALVETE, Victor. Sobre a Teoria das Uniōes Aduaneiras - sobre o que se disserta, In: Boletim de Ciências Económicas, 2000, pp. 229-546.

CALVETE, Victor. Sobre a Teoria das Uniōes Aduaneiras - sobre o que dissertar se podia. In: Boletim de Ciências Económicas, 2001, pp. 349-613.

$\mathrm{CHO}$, Sungjoon. Breaking the Barrier Between Regionalism and Multilateralism: A New Perspective on Trade Regionalism. In: Harvard International Law Journal, 2001, pp. 419-465.

CHO, Sungjoon. A Bridge Too Far: The Fall of the Fifth WTO Ministerial Conference in Cancun and the Future of Trade Constitution, In: Journal of International Economic Law, 2004, pp. 219-244.

CHOI, Won-Mog. Regional Economic Integration in East Asia: Prospect and Jurisprudence, In: Journal of International Economic Law, 2003, pp. 49-77.

CHRISTOFOROU, Theofanis. Multilateral Rules as a Constraint on Regional Rules: A Regional Perspective, In: Regionalism and Multilateralism after the Uruguay Round. Convergence, Divergence and Interaction, Paul Demaret, Jean-François Bellis e Gonzalo García Jiménez org., European Interuniversity Press, Bruxelas, 1997, pp. 757-770.

\section{COMISSÃO EUROPÉIA}

Aspectos relacionados com a OMC: dos acordos comerciais preferenciais da UE com paises terceiros, SEC (96) 2168 final, Bruxelas, 16-01-1997.

Report on United States Barriers to Trade and Investment, Bruxelas, Julho de 2000.

CROOME, John. Reshaping the World Trading System. A History of the Uruguay Round, World Trade Organization, Genebra, 1995.

CULBERT, Jay War. Time Anglo-American Talks and the Making of the GATT, In: The World Economy, 1987, pp. 381-399.

CURZON, Victoria. The Essentials of Economic Integration. Lessons of EFTA Experience. Londres: Macmillan, 1974.

DAM, Kenneth W. The GATT Law and International Economic Organization. Chicago e Londres: The University of Chicago Press, 1970.

DAVEY, William J. e PAUWELYN, Joost. MFN Unconditionality: A Legal Analysis of the Concept in View of its Evolution in the GATT/WTO Jurisprudence with Particular Reference to the Issue of "Like Product", In: Regulatory Barriers and the Principle of Non-Discrimination in World Trade Law, Thomas Cottier e Petros Mavroidis ed., Studies in International Economics - The World Trade Forum, vol. 2, The University of Michigan Press, 2000, pp. 13-50. 
DELAYGUA, Joaquim-Joan Forner. i La cláusula de la nación más favorecida: la excepción de las uniones aduaneras, de las zonas de libre cambio y de las uniones económicas. Madrid: Cívitas 1988.

DEMARET, Paul. The Metamorphoses of the GATT: From the Havana Charter to the World Trade Organization, In: Columbia Journal of Transnational Law, 1995, pp. 123-171.

DEVUYST, Youri. GATT Customs Union Provisions and the Uruguay Round: The European Community Experience, In: Journal of World Trade, 1992, pp. 15-34.

ECHANDI, Roberto. Regional Trade Integration in the Americas during the 1990s: Reflections of Some Trends and their Implications for the Multilateral Trade System, In: Journal of International Economic Law, 2001, pp. 367-410.

ESTEVADEORDAL, Antoni e SUOMINEN, Kati. Rules of Origin in the World Trading System, Paper Prepared for the Seminar on Regional Trade Agreements \& the WTO, World Trade Organization, 14-11-2003, in http://www.wto.org.

EZRAHI, Ariel. Opting Out of Opt-Out Clauses: Removing Obstacles to International Trade and International Peace, In: Law \& Policy in International Business, 1999, pp. 123-156.

FERNÁNDEZ, Raquel e PORTES, Jonathan. Returns to Regionalism: An Analysis of Nontraditional Gains from Regional Trade Agreements, In: The World Bank Economic Review, 1998, pp. 197-220.

FERREIRA, Graça Enes. A Teoria da Integração Econômica Internacional e o Modelo de Integração do Espaço Econômico Europeu. Legis Editora, 1997.

FINGER, Michael. GATT's influence on regional arrangements, in: New Dimensions in Regional Integration, Jaime de Melo e Arvind Panagariya ed., Centre for Economic Policy Research, Cambridge University Press, 1993, pp. 128-148.

FLORY, Thiébaut. La mise en place d'un nouveau système commercial multilatéral, In: La Communauté Européenne et le GATT. Évaluation des accords du cycle d'Uruguay, Thiébaut Flory org., Éditions Apogée, 1995, pp. 17-22.

FOROUTAN, Faezeh. Does Membership in a Regional Preferential Trade Arrangement Make a Country More or Less Protectionist?, In: The World Economy, 1998, pp. 309327.

FRANKEL, Jeffrey. Regional Trading Blocs in the World Economic System. Washington, D.C.: Institute for International Economics, 1997.

FRANKEL, Jeffrey. Assessing the Efficiency Gains from Further Liberalization, In: Efficiency, Equity, and Legitimacy: The Multilateral Trading System at the Millennium, 
Roger Porter, Pierre Sauvé, Arvind Subramanian e Americo Zampetti ed. Washington, D.C.: Brookings Institution Press, 2001, pp. 81-105.

FRANKEL, Jeffrey e WEI, Shang-Jin. Open versus Closed Trade Blocs, in Regionalism versus Multilateral Trade Arrangements, Takatoshi Ito e Anne Krueger ed., National Bureau of Economic Research-East Asia Seminar on Economics, vol. 6, The University of Chicago Press, 1997, pp. 119-140.

FRANKEL, Jeffrey e WEI, Shang-Jin. Open Regionalism in a World of Continental Trade Blocs, In: International Monetary Fund Staff Papers, 1998, pp. 440-453.

FRANKEL, Jeffrey, STEIN, Ernesto e WEI, Shang-Jin. Regional Trading Arrangements: Natural or Supernatural?, In: American Economic Association Papers and Proceedings, 1996, pp. 52-56.

GARAY, Luis Jorge e CORNEJO, Rafael. Rules of Origin in Free Trade Agreements in the Americas, in Trade Rules in the Making: Challenges in Regional and Multilateral Negotiations, Miguel Rodríguez Mendoza, Patrick Low e Barbara Kotschwar ed. Washington, D.C.: Organization of American States-Brookings Institution Press, 1999, pp. 261-279.

GRETHER, Jean-Marie e OLARREAGA, Marcelo. Preferential and Nonpreferential Trade Flows in World Trade, in Trade Rules in the Making: Challenges in Regional and Multilateral Negotiations, Miguel Rodríguez Mendoza, Patrick Low e Barbara Kotschwar ed. Washington, D.C.: Organization of American States-Brookings Institution Press, 1999, pp. 159-179.

GRISWOLD, Daniel. Free-Trade Agreements: Steppingstones to a More Open World, CATO Institute Trade Briefing Paper no 18, 10-7-2003.

HILPOLD, Peter. Regional Integration According to Article XXIV GATT - Between Law and Politics, In: Max Planck Yearbook of United Nations Law, 2003, pp. 219260.

HIRSCH, Moshe. International Trade Law, Political Economy and Rules of Origin: A Plea for a Reform of the WTO Regime on Rules of Origin, In: Journal of World Trade, 2002, pp. 171-188.

HOEKMAN, Bernard e KOSTECKI, Michel. The Political Economy of the World Trading System: The WTO and Beyond. 2. ${ }^{\mathrm{a}}$ ed. Oxford University Press, 2001.

HOEKMAN, Bernard e LEIDY, Michael. Holes and Loopholes in Integration Agreements: History and Prospects, Centre for Economic Policy Research Discussion Paper $\mathrm{n}^{\circ}$ 748, 1992.

HOEKMAN, Bernard e SCHIFF, Maurice. Benefiting from Regional Integration, In: Development, Trade, and the WTO: A Handbook, Bernard Hoekman, Aaditya Mattoo e Philip English ed., Washington, D.C.: The World Bank, 2002, pp. 548-558.

HUBER, Jürgen. The Practice of GATT in Examining Regional Arrangements Under Article XXIV, In: Journal of Common Market Studies, 1981, pp. 281-298. 
HUDEC, Robert E. The GATT Legal System and World Trade Diplomacy, Praeger Publishers, Nova Iorque-Washington-Londres, 1975.HUDEC, Robert e SOUTHWICK, James D. Regionalism and WTO Rules: Problems in the Fine Art of Discriminating Fairly, in Trade Rules in the Making: Challenges in Regional and Multilateral Negotiations, Miguel Rodríguez Mendoza, Patrick Low e Barbara Kotschwar ed., Organization of American States-Brookings Institution Press, Washington, D.C., 1999, pp. 47-80.

IMHOOF, Rodolphe. Le GATT et les zones de libre-échange, Imprimerie Courvoisier S.A., 1979.

IRWIN, Douglas. Multilateral and Bilateral Trade Policies in the World Trading System: An Historical Perspective, in New Dimensions in Regional Integration, Jaime de Melo e Arvind Panagariya ed., Centre for Economic Policy Research, Cambridge University Press, 1993, pp. 90-119.

IRWIN, Douglas. Free Trade Under Fire. Princeton - Nova Jersey: Princeton University Press, 2002.

JACKSON, John. World Trade and the Law of GATT. Charlottesville, Virginia: The Michie Company, 1969.

JACKSON, John. Regional Trade Blocs and the GATT, In: The World Economy, 1993, pp. 121-131.

JACKSON, John. The World Trading System. Law and Policy of International Economic Relations, 2. ${ }^{\mathrm{a}}$ ed., The Massachusetts Institute of Technology Press, 1997.

JACKSON, John, DAVEY, William e SYKES, Alan. O. Legal Problems of International Economic Relations. Cases, Materials and Text on the National and International Regulation of Transnational Economic Relations. $4^{\mathrm{a}} \mathrm{ed}$. American Casebook Series, West Group, 2002.

KRUEGER, Anne O. Free Trade Agreements versus Customs Unions, In: National Bureau of Economic Research Working Paper n. 5084, 1995.

KRUEGER, Anne O. Are Preferential Trading Arrangements Trade-Liberalizing or Protectionist? In: Journal of Economic Perspectives, 1999, pp. 105-124.

KRUEGER, Anne O. e KRISHNA, Kala. Implementing Free Trade Areas: Rules of Origin and Hidden Protection, In: Trading Blocs: Alternative Approaches to Analysing Preferential Trade Agreements, Jagdish Bhagwati, Pravin Krishna e Arvind Panagariya ed., The Massachusetts Institute of Technology Press, 1999, pp. 541-557.

KRUGMAN, Paul. Regionalism versus Multilateralism: Analytical Notes, In: New Dimensions in Regional Integration, Jaime de Melo e Arvind Panagariya ed., Centre for Economic Policy Research, Cambridge University Press, 1993, pp. 58-79.

KUILWIJK, Kees Jan. Castro's Cuba and the U.S. Helms-Burton Act: An Interpretation of the GATT Security Exemption, In: Journal of World Trade, 1997, pp. 49-61. 
KUILWIJK, Kees Jan. Power, Protection, and Free Trade: International Sources of U.S. Commercial Strategy, 1887-1939. Ithaca e Londres: Cornell University Press, 1988.

LAKE, David. Power, Protection and Free Trade: International Sources of U. S. Commercial Strategy, 1887-1939. Ithaca e Londres: Cornell University Press, 1988.

LAWRENCE, Robert Z. Regionalism, Multilateralism, and Deeper Integration: Changing Paradigms for Developing Countries, In: Trade Rules in the Making: Challenges in Regional and Multilateral Negotiations, Miguel Rodríguez Mendoza, Patrick Low e Barbara Kotschwar ed., Washington, D.C.: Organization of American States-Brookings Institution Press, 1999, pp. 23-46.

LIPSEY, R. La teoria de las uniones aduaneras: un estudio general, In: Comercio Internacional - Textos Escogidos, Introducción y selección por Jagdish Bhagwati. Madrid: Tecnos, 1975, pp. 172-188.

LLOYD, Peter. Regionalisation and World Trade, In: OCDE Economic Studies, no 18, 1992, pp. 7-43.

LLOYD, Peter. Country of origin in the global economy, In: World Trade Review, 2002, pp. 171-185.

MACHLUP, Fritz A History of Thought on Economic Integration. Londres: The Macmillan Press, 1977.

MANSFIELD, Edward D. e BRONSON, Rachel. The Political Economy of Major-Power Trade Flows, In: The Political Economy of Regionalism, Edward D. Mansfield e Helen V. Milner ed. Nova Iorque: Columbia University Press, 1997, pp. 188-208.

MANSFIELD, Edward D. e MILNER, Helen V. The Political Economy of Regionalism: An Overview, In: The Political Economy of Regionalism, Edward D. Mansfield e Helen V. Milner ed. Nova Iorque: Columbia University Press, 1997, pp. 1-19.

MARCEAU, Gabrielle e REIMAN, Cornelis. When and How Is a Regional Trade Agreement Compatible with the WTO?, In: Legal Issues of Economic Integration, 2001, pp. 297-336.

MATHIS, James. WTO, Turkey - Restrictions on Imports of Textile and Clothing Products, in Legal Issues of Economic Integration, 2000, pp. 103-114.

MAVROIDIS, Petros e HORN, Henrik. Economic and legal aspects of the Most-FavouredNation clause, in European Journal of Political Economy, 2001, pp. 233-279.

McMILLAN, John. Does regional integration foster open trade? Economic theory and GATT's Article XXIV, In: Regional Integration and the Global Trading System, Kym Anderson e Richard Blackhurst ed., Harvester Wheatsheaf, 1993, pp. 292-310.

MEADE, James. The Theory of Customs Unions. Amesterdã: North-Holland Publishing Company, 1955.

MEDEIROS, Eduardo. Raposo de Blocos Regionais de Integração Econômica no Mundo. Lisboa: Instituto Superior de Ciências Sociais e Políticas, 1998. 
MOTA, Pedro. Infante Os Blocos Econômicos Regionais e o Sistema Comercial Multilateral. O Caso da Comunidade Européia, In: Revista da Faculdade de Direito da Universidade de Lisboa, vol. XL, no 1 e 2, 1999, pp. 71-156.

NAGARAJAN, Nigel. Regionalism and the WTO: New Rules for the Game?, In: Economic Papers no 128, 1998.

ORGANIZAÇÃO DE COOPERAÇÃO E DESENVOLVIMENTO ECONÔMICO (OCDE)

Intégration Régionale et Système Commercial Multilatéral: synergie et divergence, ed. OCDE, 1995.

\section{ORGANIZAÇÃO MUNDIAL DO COMÉRCIO}

Le régionalisme et le système commercial mondial. Genebra: ed. OMC, 1995.

Committee on Regional Trade Agreements (WT/L/127), 7-2-1996.

Committee on Regional Trade Agreements, Annotated Checklist of Systemic Issues - Note by the Secretariat, (WT/REG/W/16), 26-5-1997.

Systemic Issues Related to "Other Regulations of Commerce" - Background Note by the Secretariat (WT/REG/W/17/Rev.1), 5-2-1998.

Inventory of Non-Tariff Provisions in Regional Trade Agreements, Background Note by the Secretariat (WT/REG/W/26), 5-5-1998.

Report (1999) of the Committee on Regional Trade Agreements to the General Council (WT/ REG/8), 11-10-1999.

Report (2000) of the Committee on Regional Trade Agreements to the General Council (WT/ REG/9), 22-11-2000.

Rules of Origin Regimes in Regional Trade Agreements, Background survey by the Secretariat (WT/REG/W/45), 5-4-2002.

Coverage, Liberalization Process and Transitional Provisions in Regional Trade Agreements, Background survey by the Secretariat (WT/REG/W/46), 5-4-2002.

Understanding the WTO. Genebra: ed. OMC, 2003.

World Trade Report 2003. Genebra: ed. OMC, 2003.

PALMETER, David. Rules of Origin in Regional Trade Agreements, in Regionalism and Multilateralism after the Uruguay Round. Convergence, Divergence and Interaction, Paul Demaret, Jean-François Bellis e Gonzalo García Jiménez org. Bruxelas: European Interuniversity Press, 1997, pp. 341-355.

PANAGARIYA, Arvind e SRINIVASAN, T. The New Regionalism: a Benign or Malign Growth?, in The Uruguay Round and Beyond: Essays in Honour of Arthur Dunkel, Springer, 1998, pp. 221-240. 
PARK, Sung-Hoon. Regionalism, Open Regionalism and ArticleXXIV GATT: Conflicts and Harmony, in Regional and Global Regulation of International Trade, Francis Snyder ed. Oxford-Portland Oregon: Hart Publishing, 2002, pp. 263-283.

PAUWELYN, Joost. The Puzzle of WTO Safeguards and Regional Trade Agreements, In: Journal of International Economic Law, 2004, pp. 109-142.

PESCATORE, Pierre. The Law of Integration: Emergence of a New Phenomenon in International Relations, based on the Experience of the European Communities. Leiden: Sijthoff, 1974.

POMFRET, Richard. The Economics of Regional Trading Arrangements. Oxford: Clarendon Press, 1997.

PORTO, Manuel Lopes. Os blocos regionais e o comércio mundial, In: Estudos Jurídicos e Econômicos em Homenagem ao Professor João Lumbrales. Edição da Faculdade de Direito da Universidade de Lisboa. Coimbra Editora, 2000, pp. 703-718.

PORTO, Manuel Lopes. Teoria da Integração e Políticas Comunitárias. 3. ${ }^{\mathrm{a}}$ ed. Almedina: Coimbra, 2001.

PREUSSE, Heinz. Mercosur - Another Failed Move Towards Regional Integration, in The World Economy, 2001, pp. 911-931.

REINISCH, August. Widening the US Embargo Against Cuba Extraterritorially: A Few Public International Law Comments on the 'Cuban Liberty and Democratic Solidarity (LIBERTAD) Act of 1996', In: European Journal of International Law, 1996, pp. 545-562.

ROESSLER, Frieder. The Relationship Between Regional Trade Agreements and the Multilateral Trade Order: A Reassessment, In: The Legal Structure, Functions \& Limits of the World Trade Order - A Collection of Essays by Frieder Roessler. Londres: Cameron May, 2000, pp. 181-196.

SAMPSON, Gary. Compatibility of Regional and Multilateral Trading Agreements: Reforming the WTO Process, In: American Economic Association Papers and Proceedings, 1996, pp. 88-92.

SANTOS, Luís Máximo dos, MORAIS, Luís e RICARDO, Fernando Pereira. Textos de Relaçôes Econômicas Internacionais. 2. ${ }^{a}$ ed. Associação Académica da Faculdade de Direito de Lisboa, 1999/2000.

SAPIR, André. Domino effects in Western European regional trade, 1960-1992, In: European Journal of Political Economy, 2001, pp. 377-388.

SAUVÉ, PierreeSUBRAMANIAN, Arvind. Dark Clouds over Geneva?The Troubled Prospects of the Multilateral Trading System, In: Efficiency, Equity, and Legitimacy: The Multilateral Trading System at the Millennium, Roger Porter, Pierre Sauvé, Arvind Subramanian e Americo Zampetti ed. Washington, D.C.: Brookings Institution Press, 2001, pp. 16-33. 
SCHWARTZ, Warren eSYKES, Alan. O. The economics of the most favoured nation clause, In: Economic Dimensions in International Law: Comparative and Empirical Perspectives, Jagdeep S. Bhandari e Alan O. Sykes ed., Cambridge University Press, 1997, pp. $43-79$.

SERRA, Jaime et al. Reflections on Regionalism: Report of the Study Group on International Trade, Carnegie Endowment for International Peace, Washington, D.C., 1997.

SRINIVASAN, T. Regionalism and the WTO: Is Nondiscrimination Passé?, In: The WTO as an International Organization, Anne Krueger ed., The University of Chicago Press, 1998, pp. 329-349.

STEINBERG, Richard. Transatlanticism in Support of Multilateralism? Prospects for Great Power Management of the World Trading System, in Regionalism and Multilateralism after the Uruguay Round. Convergence, Divergence and Interaction, Paul Demaret, Jean-François Bellis e Gonzalo García Jiménez org., European Interuniversity Press, Bruxelas, 1997, pp. 295-338.

STEPHENSON, Sherry. GATS and Regional Integration, In: GATS 2000: New Directions in Services Trade Liberalization, Pierre Sauvé e Robert Stern ed., Brookings Institution Press, Washington, D.C., 2000, pp. 509-529. STEPHENSON, Sherry e PRIETO, Francisco Javier.

STEPHENSON, Sherry. Multilateral and Regional Liberalization of Trade in Services, In: Trade Rules in the Making: Challenges in Regional and Multilateral Negotiations, Miguel Rodríguez Mendoza, Patrick Low e Barbara Kotschwar ed. Washington D.C.: Organization of American States-Brookings Institution Press,, 1999, pp. 235-260.

SUMMERS, Lawrence. Regionalism and the World Trading System, In: Trading Blocs: Alternative Approaches to Analysing Preferential Trade Agreements, Jagdish Bhagwati, Pravin Krishna e Arvind Panagariya ed., The Massachusetts Institute of Technology Press, 1999, pp. 561-566.

TIMBERGEN, Jan. International Economic Integration. 2. a ed. Elsevier, Amesterdã, Londres, Nova Iorque, 1965.

TREBILCOCK, Michael e HOWSE, Robert. The Regulation of International Trade. 2. ${ }^{\mathrm{a}}$ ed. Londres e Nova Iorque: Routledge, 1999.

VINER, Jacob. The Customs Union Issue, in Trading Blocs: Alternative Approaches to Analysing Preferential Trade Agreements, Jagdish Bhagwati, Pravin Krishna e Arvind Panagariya ed., The Massachusetts Institute of Technology Press, 1999, pp. 105-118.

WINTERS, Alan e SCHIFF, Maurice. Regionalism and Development: The Implications of World Bank Research for ACP and Latin American Countries, in: Journal of World Trade, 2002, pp. 479-499.

YEATS, Alexander. Does Mercosur's Trade Performance Raise Concerns about the Effects of Regional Trade Arrangements? In: The World Bank Economic Review, vol. 12, n ${ }^{\circ}$ 1, 1998, pp. 1-28. 